\title{
Phytoplankton growth formulation in marine ecosystem models: Should we take into account photo-acclimation and variable stoichiometry in oligotrophic areas?
}

\author{
S.-D. Ayata ${ }^{a, b, c, *}$, M. Lévy ${ }^{b}$, O. Aumont ${ }^{d}$, A. Sciandra $^{a}$, J. Sainte-Marie $^{c, f}$, A. Tagliabue $^{g}$, \\ O. Bernard ${ }^{\mathrm{a}, \mathrm{e}}$
}

\author{
${ }^{a}$ LOV, UMR 7093, B.P. 28, 06234 Villefranche-sur-mer, France \\ b LOCEAN-IPSL, CNRS/UPMC/IRD/MNHN, 4 place Jussieu, 75005 Paris, France \\ ${ }^{c}$ BANG, INRIA Paris-Rocquencourt, BP 105, 78153 Le Chesnay Cedex, France \\ d LPO, CNRS/IFREMER/UBO, BP 70, 29280 Plouzané, France \\ e BIOCORE, INRIA, B.P. 93, 06902 Sophia-Antipolis Cedex, France \\ f Laboratoire Saint-Venant, 6 quai Watier, 78401 Chatou Cedex, France \\ ${ }^{g}$ Dept. of Earth, Ocean and Ecological Sciences, School of Environmental Sciences, University of Liverpool, 4 \\ Brownlow Street, Liverpool L69 3GP, United Kingdom
}

*: Corresponding author : S.-D. Ayata, email address : sakina.ayata@normalesup.org

\begin{abstract}
:
The aim of this study is to evaluate the consequences of accounting for variable Chl:C (chlorophyll:carbon) and $\mathrm{C}: \mathrm{N}$ (carbon:nitrogen) ratios in the formulation of phytoplankton growth in biogeochemical models. We compare the qualitative behavior of a suite of phytoplankton growth formulations with increasing complexity: 1) a Redfield formulation (constant C:N ratio) without photoacclimation (constant Chl:C ratio), 2) a Redfield formulation with diagnostic chlorophyll (variable and empirical Chl:C ratio), 3) a quota formulation (variable C:N ratio) with diagnostic chlorophyll, and 4) a quota formulation with prognostic chlorophyll (dynamic variable). These phytoplankton growth formulations are embedded in a simple marine ecosystem model in a 1D framework at the Bermuda Atlantic Time-series (BATS) station. The model parameters are tuned using a stochastic assimilation method (micro-genetic algorithm) and skill assessment techniques are used to compare results. The lowest misfits with observations are obtained when photo-acclimation is taken into account (variable $\mathrm{Chl}: \mathrm{C}$ ratio) and with non-Redfield stoichiometry (variable $\mathrm{C}: \mathrm{N}$ ratio), both under spring and summer conditions. This indicates that the most flexible models (i.e., with variable ratios) are necessary to reproduce observations. As seen previously, photo-acclimation is essential in reproducing the observed deep chlorophyll maximum and subsurface production present during summer. Although Redfield and quota formulations of $\mathrm{C}: \mathrm{N}$ ratios can equally reproduce chlorophyll data the higher primary production that arises from the quota model is in better agreement with observations. Under the oligotrophic conditions that typify the BATS site no clear difference was detected between quota formulations with diagnostic or prognostic chlorophyll.
\end{abstract}




\section{Highlights}

We compare phytoplankton growth formulations with increasing complexity, after tuning through microgenetic algorithm. The most flexible models, i.e., with variable ratios, are necessary to reproduce observations under oligotrophic regimes. Photo-acclimation (variable $\mathrm{Chl}: \mathrm{C}$ ) is needed to reproduce the subsurface chlorophyll maximum in summer. Non-Redfield stoichiometry (variable $\mathrm{C}: \mathrm{N}$ ) is needed to simulate more realistic primary production estimates. No clear difference is detected between quota (non-Redfield) formulations with diagnostic or prognostic chlorophyll.

Keywords: Biogeochemical modeling ; Phytoplankton ; Photo-acclimation ; Redfield ratio ; Internal quota ; BATS ; Optimization ; Micro-genetic algorithm

\section{Introduction}

During the last twenty years, marine ecosystem (or biogeochemical) models have been widely used to study the response of primary production to perturbation of the physical environment along a wide range of temporal and spatial scales. Most of these models follow the same general structure: they use nitrogen as the main currency, and account for a simplified food-web 
which generally includes phytoplankton and zooplankton, and a regeneration network with detritus, dissolved organic nitrogen, and various nutrients (i.e., Fasham et al., 1990). Whereas the complexity of marine biogeochemical models has increased in the last decade (reaching sometimes about eighty state variables as in Follows et al., 2007), simple phytoplankton growth models are still usually embedded within these ecosystem models, with strong simplifications on phytoplankton physiology, such as using constant C:N stoichiometry or not accounting for photo-acclimation (using constant Chl:C ratio).

Phytoplankton growth formulations involving different complexities in the representation of physiological processes (such as photosynthesis, nutrient uptake, photo-acclimation, or energy storage) have been derived from laboratory experiments (Zonneveld, 1998; Baklouti et al., 2006). However, directly transposing the relationships derived from these laboratory experiments, which generally involve a single phytoplankton species and explore a limited set of forcing conditions (nutrient supply, temperature, light), to global marine ecosystem models is not straightforward and is currently the subject of some debates (Flynn, 2003a; Franks, 2009; Flynn, 2010; Anderson, 2010).

The simplest phytoplanktonic growth formulations use a classical MichaelisMenten representation of nutrient uptake (Monod, 1949, 1950) and assume constant stoichiometry between carbon, nitrogen and phosphorus (Redfield et al., 1963). In these models, phytoplankton are represented by a single state variable, the phytoplankton biomass, expressed in nitrogen, phosphorus or carbon currency. Because of their relative simplicity, these models are generally used for global scale studies (Aumont and Bopp, 2006; Follows et al., 
2007; Dutkiewicz et al., 2009). More sophisticated formulations, inspired from the original work of Droop $(1968,1983)$, explicitly account for the dynamics of internal quotas of phytoplanktonic cells (Flynn, 2008; Klausmeier et al., 2004; Bougaran et al., 2010; Mairet et al., 2011; Bernard, 2011). In these formulations, phytoplankton are represented by at least two variables, usually the phytoplankton biomass in both carbon and nitrogen currency. This allows to decouple the dynamics of nutrient uptake from carbon fixation, depending on the physiological state of phytoplankton. Various versions of such formulations have been successfully applied to 1D marine ecosystem models (Lancelot et al., 2000; Allen et al., 2002; Lefèvre et al., 2003; Mongin et al., 2003; Blackford et al., 2004; Salihoglu et al., 2008) and also attempted in 3D ecosystem models (Tágliabue and Arrigo, 2005; Vichi et al., 2007; Vichi and Masina, 2009; Vogt et al., 2010).

The dynamics of pigment contents, most frequently of chlorophyll $a(\mathrm{Chl})$, can also be represented with different levels of complexity. The Chl:C ratios can either be constant (no photo-acclimation), diagnostic (from an empirical (Cloern et al., 1995; Bernard, 2011) or a mechanistic (Geider and Platt, 1986; Doney et al., 1996; Bissett et al., 1999) static relationship), or prognostic (i.e., with a dynamic evolution) (Flynn and Flynn, 1998; Geider et al., 1998; Baumert and Petzoldt, 2008; Ross and Geider, 2009). For instance, Geider et al. (1998) proposed a phytoplankton growth formulation calibrated for chemostat experiments, in which chlorophyll production is proportional to both nitrogen assimilation and carbon fixation.

The different behaviours associated to these different growth formulations have generally been examined in the context of laboratory experiments 
(Vatcheva et al., 2006), i.e. for monospecific cultures under a limited set of idealized forcing. Significant variations from Redfield stoichiometry observed in experimental data of nutrient-limited phytoplankton cultures have highlighted the limits of the Redfield-Monod-type models and the need for non-Redfieldian formulations (quota formulations) (Sciandra, 1991; Dearman et al., 2003; Flynn, 2003a, 2010). Besides, formulations that assume constant Chl:C ratio fail to reproduce experimental data (Flynn et al., 2001) or in situ observations (Doney et al., 1996; Lévy et al., 1998; Spitz et al., 1998). However, it is not straightforward to find the right trade-off between a model which is too simple to reproduce the observed dynamics and a complex model with too many free parameters to tune against limited data (Flynn, 2003b). Based on comparisons with laboratory experiments, Flynn (2003a) suggested that quota-type models with empirical Chl:C relationship "should be adequate for most oceanographic modeling scenarios", although it must be kept in mind that even if a model using simplified assumptions may fit to observed data, it may not be acceptable (Mitra et al., 2007; Flynn, 2010).

A rigorous comparison of the qualitative and quantitative behaviours of Redfield, quota-type, and mechanistic models in more realistic oceanic conditions remains an open question. Based on model results at the Bermuda Atlantic Time-series Study (BATS) site, Schartau et al. (2001) suggested that an optimized model (i.e., after data assimilation procedure) with Redfield stoichiometry may not be able to correctly simulate primary production in oligotrophic subtropical regions, but, in an optimized marine ecosystem model of the Northwestern Mediterranean Sea, Faugeras et al. (2003) could not decipher significant differences between Redfield and quota growth for- 
mulations.

In this context, the present work aims at comparing, in a rigorous framework, the qualitative and quantitative behaviours of different formulations of phytoplankton growth in an oceanographic context and to determine whether increasing complexity leads to significant improvement of the seasonal dynamics of phytoplankton. This is examined with a $1 \mathrm{D}$ ecosystem model which simulates a seasonal cycle at BATS station. This site was chosen because strongly variable $\mathrm{Chl}: \mathrm{C}$ and $\mathrm{C}: \mathrm{N}$ ratios have been observed at this station over the year (for the phytoplankton and the particulate organic matter, respectively; Sambrotto et al., 1993; Michaels and Knap, 1996; Steinberg et al., 2001). A coherent suite of consistent phytoplankton growth formulations is constructed by adding stepwise complexity. Constant, diagnostic, and prognostic Chl:C ratios are considered with Redfield stoichiometry or with variable $\mathrm{C}: \mathrm{N}$ ratio. All formulations are then incorporated within the same ecosystem model applied in a 1D framework at BATS. Data assimilation through micro-genetic algorithm is used to calibrate the different models. This enables to compare the different formulations on the basis of their best performance relatively to standard observations.

After briefly presenting the study site, we describe the general structure of the marine ecosystem model and the different phytoplankton growth formulations. Then we present the micro-genetic algorithm used to tune the model parameters. In the Results section, the outputs of the different formulations are described and the skill of each formulation to reproduce observations is assessed. Finally, the choice of the phytoplankton growth formulation in marine biogeochemical models is discussed. 


\section{Models and methods}

\subsection{Study site}

The Bermuda Atlantic Time-series Study (BATS) site is located in the Sargasso Sea, in the western North Atlantic subtropical gyre (31 $40^{\prime} \mathrm{N}$, 64²' W). This station has been monthly sampled since October 1988 as part of the US Joint Global Ocean Flux Study (JGOFS) program and the data are freely available at http://bats.bios.edu/index.html. The seasonal dynamics of nitrate, chlorophyll and primary production at BATS have been described by Steinberg et al. (2001). In winter, strong vertical mixing supplies nutrients to the surface layers, allowing a moderate bloom to occur between January and March. In summer, nutrient supply collapses because of thermal stratification and primary production is low, with a subsurface chlorophyll maximum (60-120 m). In situ measurements also indicate that the stoichiometric ratios of particulate $\mathrm{C}, \mathrm{N}$ and $\mathrm{P}$ deviate from the traditional Redfield ratios, especially during the oligotrophic summer (Michaels and Knap, 1996; Cotner et al., 1997; Steinberg et al., 2001).

\subsection{General model structure}

The general structure of the model is a simple 'NPZD' type ecosystem, used in a 1D-framework which simulates the seasonal cycle of phytoplankton at BATS station. We used the LOBSTER marine ecosystem model, which has been previously used and calibrated for the North Atlantic (Lévy et al., 2005; Kremeur et al., 2009; Lévy et al., 2012). Besides phytoplankton $\left(\mathrm{P}_{N}\right)$, the ecosystem model has five additional prognostic variables expressed in nitrogen units $\left(\right.$ mmolN.m $\left.{ }^{-3}\right)$ : Nitrate $\left(\mathrm{NO}_{3}\right)$, Ammonium $\left(\mathrm{NH}_{4}\right)$, Zooplankton 
$\left(\mathrm{Z}_{N}\right)$, Detritus $\left(\mathrm{D}_{N}\right)$, and Dissolved Organic Matter (DOM) (Fig. 1). The photosynthetic available radiation (PAR) is derived from a two-wavelengths light absorption model, with absorption coefficients depending on the local phytoplankton concentrations. The detailed equations of the LOBSTER model are presented in Table 1 . The definition of the parameters and their default values are presented in Table 2.

\subsection{Model implementation}

The ecosystem model is embedded in a simple 1D physical model, which accounts for the observed seasonal evolution of the mixed layer depth (MLD) and temperature at BATS in 1998. The 1D-model has 30 vertical layers, with a vertical discretization of $10 \mathrm{~m}$ from $0-100 \mathrm{~m}$ and then increasing with depth. Only vertical diffusion is taken into account. Monthly values of observed MLD, temperature and salinity at BATS in 1998 are used and linearly interpolated in time at each model time-step. The vertical eddy diffusivities $K_{z}$ are diagnosed from the MLD: they are set to $1 \mathrm{~m}^{2} . \mathrm{s}^{-1}$ within the mixed layer and to $10^{-5} \mathrm{~m}^{2} \cdot \mathrm{s}^{-1}$ below the mixed layer. A specific reaction term sms (source minus sink) is added to the diffusion equation. For each of the state variables $i$, the prognostic equation reads as follows:

$$
\frac{\partial C_{i}}{\partial t}=\frac{\partial}{\partial z}\left(K_{z} \frac{\partial C_{i}}{\partial z}\right)+\operatorname{sms}\left(C_{i}\right)
$$

where $C_{i}$ is the tracer concentration. The initial nitrate conditions are set to in situ observations at BATS in January 1998, whereas they are set to $0.1 \mathrm{mmolN} . \mathrm{m}^{-3}$ for the dissolved organic matter, to $0.03 \mathrm{mmolN} . \mathrm{m}^{-3}$ for the ammonium (Lipschultz, 2001), and to extremely low values for the other 
state variables $\left(10^{-8} \mathrm{mmolN} . \mathrm{m}^{-3}\right)$. The biophysical model is spun up for one year and a time step of 1.2 hours is used.

\subsection{Increasing the complexity in the representation of phytoplankton}

The complexity of phytoplankton growth formulations is progressively increased. Four levels of complexity are compared: 1) a Redfield formulation with constant Chl:C ratio, 2) a Redfield formulation with a diagnostic Chl:C ratio, 3) a quota formulation with a diagnostic Chl:C ratio, and 4) a quota formulation with a prognostic Chl:C ratio. In these formulations, the phytoplankton compartment is thus represented by 1,2 or 3 state variables. For convenience, these formulations have then been named P1.0, P1.5, P2.5, and P3.0 respectively, with the arbitrary convention that a prognostic state variable counts for one and a diagnostic variable (chlorophyll) counts for a half.

\subsubsection{Redfield stoichiometry and constant Chl:C ratio (P1.0 formulation)}

In the simplest formulation, phytoplankton are represented by a unique state variable (P1.0 formulation) (Fig. 2A, Tables 4 and 5). The phytoplankton carbon biomass $P_{C}$ and nitrogen biomass $P_{N}$ are related by a constant Redfield ratio $R_{C: N}=P_{C} / P_{N}=6.56$ molC.molN ${ }^{-1}$. The Chl:C ratio $R_{C h l: C}$ of the phytoplanktonic cells is also assumed to be constant and equal to 1/60 gChl.gC $\mathrm{gC}^{-1}$ (Fasham et al., 1990). Nitrogen uptake accounts for light and nutrient limitation. Light limitation $L_{I}$ is defined according to Webb et al. (1974). Note that in order to keep the models as simple as possible, this expression is shared by the four phytoplankton growth formulations P1.0, P1.5, P2.5, and P3.0. Nutrient-limitation $L_{N}$ is expressed as the sum 
of nitrate and ammonium limitations following Wroblewski (1977) and as used in Fasham et al. (1990). Primary production (in carbon currency) is proportional to nutrient uptake (in nitrogen currency) by the factor $R_{C: N}$.

\subsubsection{Redfield stoichiometry and diagnostic Chl:C ratio (P1.5 formulation)}

The structure of the P1.5 formulation is similar to that of P1.0, except that photo-acclimation is accounted for (Tables 4 and 5). In this model, the phytoplanktonic chlorophyll:carbon ratio $R_{C h l: C}$ is thus a diagnostic variable (Fig. 2B), calculated following Geider et al. (1996, 1998) as a function of light and nutrient limitation.

\subsubsection{Cell quota and diagnostic Chl:C ratio (P2.5 formulation)}

In the P2.5 formulation, the phytoplanktonic nitrogen:carbon ratio $Q=$ $P_{N} / P_{C}$ is variable (quota formulation) (Tables 4 and 5 ). The phytoplanktonic compartment is thus represented by two state variables: the phytoplanktonic nitrogen biomass $P_{N}$ and the phytoplanktonic carbon biomass $P_{C}$ (Fig. 2C). As in P1.5, the phytoplanktonic chlorophyll:carbon ratio $R_{C h l: C}$ is a diagnostic variable calculated following Geider et al. (1998). The formulations of nutrient uptake and primary production have also been chosen following Geider et al. (1996, 1998). Nutrient uptake (in nitrogen currency) is expressed as the product of quota and nutrient limitation terms. Primary production (in carbon currency) is expressed as the product of quota and light limitation terms.

\subsubsection{Cell quota and prognostic chlorophyll (P3.0 formulation)}

The P3.0 formulation corresponds to P2.5 with the addition of a fully prognostic equation for chlorophyll (Tables 4 and 5). Phytoplankton are thus 
represented by three state variables: phytoplanktonic nitrogen biomass $P_{N}$, phytoplanktonic carbon biomass $P_{C}$, and chlorophyll biomass $P_{C h l}$ (Fig. 2D). The dynamical equation of the phytoplanktonic chlorophyll $P_{C h l}$ is defined following Geider et al. (1998): the chlorophyll production is a function of nitrogen uptake, carbon fixation (production) and light and it does not respond rapidly to environmental changes when using the original set of parameters.

\subsubsection{Geider model (GP3.0 formulation)}

All previous formulations share the same expression of light limitation, which is independent of nutrient limitation and internal C:N quota, an assumption that can be discussed (Flynn, 2003b, 2008). To check the consequences of this assumption, a fifth model is constructed from P3.0 by using the following light limitation term, which now depends on the internal C:N quota $Q$ :

$$
L_{I}(Q)=\left[1-E X P\left(-\frac{\alpha \cdot R_{C h l: C \cdot P A R}}{\mu_{m} \cdot \frac{Q-Q_{0}}{Q_{\max }-Q_{0}}}\right)\right]
$$

This new formulation, named GP3.0, corresponds to the original phytoplankton growth formulation proposed by Geider et al. $(1996,1998)$, and which has been previously incorporated in various marine ecosystem models (e.g., Moore et al., 2002; Lefèvre et al., 2003).

\subsection{Parameter tuning using micro-genetic algorithm}

Model parameters are tuned using a micro-genetic algorithm to best fit the observed seasonal cycle at BATS. Genetic algorithms are stochastic methods in which a population of parameters evolves with mutation/selection processes (evolutionary tuning approach). In the particular case of micro-genetic algorithms, the size of the population is small and no mutation is considered 
(Carroll, 1996). A micro-genetic algorithm with binary coding, elitism, tournament selection of the parents, and uniform cross-over was used (Carroll, 1996; Schartau and Oschlies, 2003). At the beginning, a set (or population) of parameter vectors (individuals) is randomly generated within a predefined range (Table 7). Each parameter vector is coded as a binary string (chromosome). Then, at each generation, the misfit of each parameter vector (fitness of each individual) is estimated as the misfit (cost function) between the data and the model outputs for this parameter vector. The parameter vector with the lowest misfit (best individual of its generation or 'elite') is conserved to the next generation. Then, four vectors are randomly chosen and associated in two pairs. The vectors with the lowest misfit (best fitness) within each pair are selected (parents), and a new parameter vector (child) is produced by randomly crossing each bit of the two selected vectors. This process (reproduction) is repeated until the replenishment of the population. New generations are produced (evolution), until the population of parameter vectors has converged (all the vectors are identical to the elite). Then, a new generation is randomly generated, with the elite conserved. This process was repeated 500 times for a population whose size was chosen equal to the number of parameters to identify (Schartau and Oschlies, 2003). For each model, the parameter space was reduced to the parameters for which the cost function was the most sensible, as learnt from preliminary sensibility analyses (four to six parameters depending on the model, see Table 7).

\subsection{Cost function and model comparison}

In situ data measured at BATS in 1998, including monthly records of nitrate concentration, total particulate organic nitrogen concentration, chloro- 
phyll concentration, and primary production, are used for optimization. In the model, total particulate organic nitrogen $(\mathrm{PON})$ is taken as the sum of phytoplanktonic nitrogen, zooplanktonic nitrogen and detritus: $P O N=$ $P_{N}+Z_{N}+D_{N}$. These monthly profiles are re-gridded along the $1 \mathrm{D}$ vertical grid of the model. The cost function $F$ is taken as the weighted sum of squared differences between monthly vertical profiles of observations ${ }_{o b s}(k, l)$ and model outputs $\bmod _{n}(k, l)$ (Evans, 2003; Stow et al., 2009):

$$
F=\frac{1}{K L} \sum_{n=1}^{N} \sum_{k=1}^{K} \sum_{l=1}^{L} W_{n}\left[o b s_{n}(k, l)-\bmod _{n}(k, l)\right]^{2}
$$

Four data types are used $(N=4)$ : nitrate concentration, chlorophyll concentration, total particulate organic nitrogen and primary production. The cost function is calculated from monthly data $(\mathrm{L}=12)$ and only the first vertical layers from 0 to $168 \mathrm{~m}$ are used $(\mathrm{K}=15)$. The weights $W_{n}$ are chosen equal to the inverse of the standard deviation of the monthly observations $\left(1 / \sigma_{n}\right)$, with $\sigma_{N O_{3}}=0.541 \mathrm{mmolN} \cdot \mathrm{m}^{-3}, \sigma_{C h l}=0.080 \mathrm{mgChl} . \mathrm{m}^{-3}, \sigma_{P O N}=0.106$ mmolN.m ${ }^{-3}, \sigma_{P P}=0.177 \mathrm{mmolC} \cdot \mathrm{m}^{-3} \cdot \mathrm{d}^{-1}$.

Model outputs are also compared with in situ data and with each other using skill assessment technics, such as Taylor diagrams and target diagrams (Taylor, 2001; Stow et al., 2009; Jolliff et al., 2009). These diagrams can be seen as complementary indicators of the misfit between data and model outputs, including correlation, root mean squared differences, relative standard deviations, and bias. 


\section{Results}

\subsection{Parameter tuning using micro-genetic algorithm}

For each phytoplankton growth formulation, four to six parameters are identified trough an optimization algorithm, with the number of optimized parameters increasing with the formulation complexity. The parameter values obtained after optimization are in the same range of magnitude among the different models (Table 8). We can note that, after optimization and compared to their initial default values, grazing parameters $\left(K_{g}, g\right)$ and maximal Chl:N ratio $\left(R_{C h l: N}^{M a x}\right)$ are increased, whereas the other parameters remain close to their default values. For each model, the best constrained parameter is the initial PI slope $\alpha$ (as indicated by the evolution of the minimum misfit obtained for each of the 64 possible values of this parameter during the optimization procedure, not shown).

After optimization, cost functions are reduced for all models, by $23 \%$ for P1.0 to $38 \%$ for P2.5 (Table 8). Model performances to reproduce all data types are improved (Fig. 3). The optimizations increase the correlation between the model outputs and the observations (angular coordinates on the Taylor diagram) and decrease the ratio of the standard deviations of model outputs and observations (radial coordinates on the Taylor diagram). Optimizations also decrease the bias and the normalized unbiased root mean squared differences between model outputs and observations (abscissae and ordinates on the Target digram). Nitrate is the observation which is globally best reproduced by all models, contrary to particulate organic nitrogen $(\mathrm{PON})$. 


\subsection{Seasonal dynamics}

The temporal evolution of the vertical profiles of nitrate, PON, chlorophyll and primary production confirms that all the models, after the parameter identification procedure, behave similarly. This may suggest a strong impact of the initial conditions and physical forcing (Fig. 4). The evolutions of nitrate and PON distributions are not significantly different between the phytoplankton growth formulations. In response to the deepening of the mixed layer in March, nitrate is entrained to the surface. It is then quickly consumed in the euphotic layer during winter and spring, leaving very low nitrate concentrations in summer. Accordingly, PON and chlorophyll exhibit a strong seasonal variability with a strong contrast between winter/spring and summer. A strong phytoplankton bloom occurs between March and April, characterized by high PON and chlorophyll concentrations in the surface mixed layer, followed by a subsurface maxima in chlorophyll in summer.

Larger differences between phytoplankton growth formulations can be seen in chlorophyll and production, with larger discrepancies between simulations and observations than among simulations (Fig. 4). None of the model correctly reproduces the exact dynamics of the observations. All models are able to reproduce the subsurface chlorophyll maximum in summer, but simulated chlorophyll concentrations are lower than observed whatever the model, except during the bloom. None of the models is able to reproduce the observed temporal evolution of production, which is characterized by a maximum value in February and high values during the oligotrophic season. However, the high production period is longer for quota formulations. As expected from previous studies (Doney et al., 1996; Spitz et al., 1998), 
the Redfield formulation with constant $\mathrm{Chl}$ : C ratio $(\mathrm{P} 1.0)$ is unable to simultaneously reproduce the deep chlorophyll maximum and the subsurface production maximum during the oligotrophic season, because of its constant Chl:C ratio (Fig. 5). Conversely, models with photo-acclimation (i.e., variable Chl:C ratio) are all able to simulate the deep chlorophyll maximum and the subsurface production maximum during the oligotrophic season. Taking into account photo-acclimation allows to increase the $\mathrm{C}$ :Chl ratio in surface, especially during oligotrophic conditions (Fig. 5).

The cell quota formulations with photo-acclimation (P2.5, P3.0 and GP3.0) exhibit significant differences from the Redfield formulations in terms of $\mathrm{C}$ :Chl ratio, phytoplankton biomass in carbon, and $\mathrm{C}: \mathrm{N}$ ratio, particularly during oligotrophic conditions (Fig. 5). During the bloom, lower C:Chl and $\mathrm{C}: \mathrm{N}$ ratios are simulated by the models that allow these ratios to vary. During the oligotrophic period, higher $\mathrm{C}$ : $\mathrm{Chl}$ and $\mathrm{C}: \mathrm{N}$ ratios are simulated at the surface by these models, with very close values for the three formulations. The Redfield formulation with photo-acclimation (P1.5) simulates the lowest variations of the $\mathrm{C}$ :Chl ratio, suggesting that this model could be less efficient than the quota formulations to simulate photo-acclimation, likely because it is less flexible.

\subsection{Annual and seasonal production in carbon and nitrogen}

In general, similar total and new productions in nitrogen are simulated by the different models (relative differences about $5 \%$ ), except for the new production between P1.0 and P2.5 (about $30 \%$ higher for P2.5) (Table 9). F-ratios vary from 0.43 to 0.49 during the bloom and from 0.20 to 0.27 during the oligotrophic period. Total productions in carbon are much larger 
for the formulations with a variable $\mathrm{C}: \mathrm{N}$ quota than for the Redfield formulations (about $50 \%$ larger). This increase in carbon production is simulated both during the bloom and during oligotrophic conditions, suggesting a more efficient photosynthesis per chlorophyll content. Temporal evolution of vertically-integrated daily production in nitrogen are close between models, whereas strong differences are observed in vertically-integrated daily production in carbon between Redfield and quota formulations, both during the bloom and in summer (Fig. 6).

With cell quota formulations (P2.5, P3.0 and GP3.0), the C:N ratio of total production is higher than the Redfield ratio and it increases at the surface in summer, i.e. during oligotrophic conditions, with the highest C:N values simulated by GP3.0 (about 15 at the surface at the end of the year) (Fig. 7). Note that this feature is an emergent property of these cell quota formulations, since the value of the $\mathrm{C}: \mathrm{N}$ ratio was not constrained during the optimization procedure. Besides, with the cell quota formulations the $\mathrm{C}: \mathrm{N}$ ratio of total production is always higher than the $\mathrm{C}: \mathrm{N}$ ratio of phytoplankton, because of the cost of the nitrogen uptake ( $\zeta$ parameter). With the P2.5 formulation, for instance, the $\mathrm{C}: \mathrm{N}$ ratios of total production and of phytoplankton vary between 9 and $14 \operatorname{molC} \cdot \operatorname{mol} N^{-1}$ and between 5 and $10 \operatorname{molC} . \operatorname{mol} N^{-1}$, respectively.

\section{Discussion}

The aim of the present work was to assess the consequences of taking into account photo-acclimation and variable stoichiometry of the phytoplankton growth in marine ecosystem models, by comparing the qualitative and quan- 
titative behaviours of several growth formulations within a rigorous framework. A parameter tuning based on optimization procedure was performed before the comparison, using observed data of nitrate, particulate organic nitrogen (PON), chlorophyll, and primary production at BATS. The optimization increases the ability of all models to reproduce the observed data. Globally, all models behave similarly after optimization and no difference in the ability to reproduce nitrate or PON data is observed. However, as expected from previous studies at BATS (Doney et al., 1996; Spitz et al., 1998), photo-acclimation (i.e., a variable Chl:C ratio) is needed to simultaneously reproduce subsurface production and deep chlorophyll maximum during oligotrophic conditions in summer. Moreover, Redfield formulations underestimated production compared to quota formulations, which suggests that the latter should be preferred. No clear difference is detected between quota formulations with diagnostic or prognostic chlorophyll. Our main conclusion it that quota formulations with diagnostic or prognostic chlorophyll enable to simulate more realistic values of chlorophyll and phytoplankton production during oligotrophic conditions, compared with formulations with constant Chl:C and C:N ratios. Indeed, these formulations are able to simulate a more 'flexible' phytoplankton physiology. They are then able to better reproduce the phytoplankton dynamics under a wider range of environmental conditions.

\subsection{Parameter tuning}

In order to compare the different phytoplankton growth formulations, we have followed the methodology which consists in calibrating parameters prior to comparison using advanced parameter estimation approaches (Faugeras 
et al., 2004; Friedrichs et al., 2006; Smith and Yamanaka, 2007; Ward et al., 2010; Bagniewski et al., 2011). This ensures that all models performed the best they could. Sensitivity analyses have been needed to properly choose the cost function and the parameters to calibrate with the optimization procedure: the sensitivity of several cost functions have been tested a priori and only the most constrained parameters have been selected as candidates for the minimization algorithm. Optimization procedure also provides a posteriori estimates of the parameter uncertainty (Matear, 1995; Fennel et al., 2001; Faugeras et al., 2003; Schartau and Oschlies, 2003). For instance, using dissolved inorganic nitrogen, PON, chlorophyll, silicate, and oxygen data to optimize the parameters of a simple marine ecosystem model through variational optimization, Bagniewski et al. (2011) concluded that phytoplankton parameters (such as $\mu, \alpha$, and $m_{P}$ ) were better constrained than zooplankton parameters (such as $g$ ). In the present study, the strength of the minimization algorithm has been qualitatively estimated from the shape of the misfit function for each of the selected parameters. The best constrained parameter is the initial PI slope $\alpha$, which is not surprising since this parameter appears in the equations of nitrate, PON, chlorophyll, and primary production, i.e., the data used during the optimization procedure.

\subsection{Model framework}

For the purpose of our study, we used a relatively simple biogeochemical model and the annual primary production in carbon was underestimated with all the phytoplankton growth formulations (assuming the production data are correct). This shortcoming is a problem faced by most biogeochemical models in the North Atlantic subtropical gyre (see for instance Oschlies, 
2002). Several reasons can been advanced to explain it. One reason is the use of a simple 1D physical framework, since lateral transport, which could provide an additional source of DOM that would then be remineralized in situ (Williams and Follows, 1998), and nutrient supply by mesoscale and submesoscale processes (Oschlies, 2002; McGillicuddy et al., 2003; Lévy et al., 2012) may significantly increase the production in the North Atlantic. A second hypothesis is the lack of nitrogen-fixers in our model. Finally, a third hypothesis would be that the structure of the model is not complex enough, in particular because of the lack of explicit bacteria. Indeed, this compartment may play an important role during summer, especially for regenerated production (Steinberg et al., 2001). However, the presence of a DOM pool in our model implicitly assumes remineralization through bacterial activity and allows local remineralization of the organic matter being produced. Besides, the LOBSTER model have been complexified with an explicit representation of bacteria and the versions of LOBSTER with and without bacteria have been compared in the Mediterranean sea and showed little differences in terms of primary production, even during the summer oligotrophic period (Lévy et al., 1998). Moreover, sensitivities to the DOM remineralization rate, which mimics the action of bacteria, did not enable to significantly change the simulated primary production, further highlighting that the reason for this might more probably be the lack of nitrogen sources in the model rather than to the simplified microbial network. This model could also have been improved by the representation of additional phytoplankton types, since the composition of the phytoplankton community changes along the year, or by the use of additional nutrients such as phosphate (Cotner et al., 1997; 
Steinberg et al., 2001), but then it would have required to take into account multi-nutrient growth limitation of phytoplankton. Although a better agreement between model and observation might then be obtained using a more complex biogeochemical model and/or a more realistic physical forcing, the model framework can be used to compare the different phytoplankton growth formulations in a robust manner.

\subsection{Photo-acclimation in marine biogeochemical models}

Our comparative modelling study at BATS suggests that taking into account photo-acclimation (i.e., a variable $\mathrm{Chl}$ :C ratio) is mandatory to simultaneously reproduce deep chlorophyll maximum and subsurface primary production during oligotrophic conditions. Indeed, a model without photoacclimation (P1.0) is able to predict the spring bloom and the depth of the chlorophyll maximum, but has difficulties to reproduce the high production observed in summer in subsurface, compared to the formulations with photoacclimation that are more flexible. Since in the latter formulations the Chl:C ratio can vary depending on environmental conditions (namely light and nutrient availability), they can better perform along a wider range of conditions (surface and subsurface, spring and summer).

These results are in agreement with previous modelling studies at BATS indicating that the phytoplankton dynamic could not be reproduced when using a constant Chl:C ratio (Doney et al., 1996; Hurtt and Armstrong, 1996, 1999; Spitz et al., 1998, 2001; Fennel et al., 2001). Doney et al. (1996) hypothesized that this may be "because not enough nutrient were available to sustain [the production in summer]". Our comparative study highlights that difficulties to simulate the high production in summer may partly be 
due to the fixed Chl:C ratio, since models with variable Chl:C were able to reproduce the observations better. Similarly, Fennel et al. (2001) and Spitz et al. (1998) could not correctly reproduce observation data at BATS with simple NPZD models with constant Redfield and Chl:N ratios, even after parameter optimization. Fennel et al. (2001) suggested that this was due to the physical forcing and/or to the too simple hypotheses of the ecosystem model, whereas Spitz et al. (1998) proposed three possible explanations for this failure: the use of a Redfield stoichiometry, the absence of photoacclimation, and approximations about vertical processes. In the present study, the same physical forcing is used for all models and our results indicate that the failure to reproduce the nitrate and chlorophyll data may be due to the absence of photo-acclimation (constant Chl:N ratio). Our results are in agreement with the improvements of the Fasham model proposed by Hurtt and Armstrong $(1996,1999)$ using a variable Chl:N ratio as a function of the irradiance, or by Spitz et al. (2001) using a prognostic Chl:N ratio: photo-acclimation of phytoplankton should be taken into account to simulate the subsurface chlorophyll maximum under summer oligotrophic conditions. In summer this chlorophyll maximum is observed in subsurface, with maximum production rates at the surface. This means that the phytoplankton decrease its pigment content at the surface and increase it to collect more light in subsurface. Our results suggest that such flexibility in phytoplankton physiology can only be simulated in marine ecosystem models if the ratio of pigment content over biomass can vary depending on environmental conditions (photo-acclimation).

Our suite of numerical experiments also allows to compare several formu- 
lations of photo-acclimation. The P2.5 formulation, with diagnostic chlorophyll, and the P3.0 formulation, with fully dynamical chlorophyll, produced relatively similar results. Slight differences were observed between the P3.0 and the GP3.0 formulations, both with dynamical chlorophyll but with different light limitation formulations. In the latter, light limitation is a function of the cell quota, as recommended by Flynn (2003b) to assure that, at steady state, the growth-irradiance curve has the correct initial slope. However, phytoplankton growth in the ocean is often not at steady state. Additional data on phytoplanktonic carbon concentration and $\mathrm{C}: \mathrm{N}$ ratio would be needed to constrain these cell quota formulations with photo-acclimation and compare their ability to reproduce phytoplanktonic dynamics. In the meantime, and as suggested by Flynn (2003a) from growth formulation comparison for laboratory experiments, phytoplankton models with diagnostic chlorophyll should be preferred when coupled with marine ecosystem models.

\subsection{Stoichiometry of phytoplanktonic production}

Our results indicate that compared to Redfield growth formulations, quota growth formulations better reproduce the primary production during oligotrophic conditions. Several problems arose from previous modelling studies at BATS using constant $\mathrm{C}: \mathrm{N}$ ratios with photo-acclimation because of the assumed Redfield stoichiometry. Schartau et al. (2001) concluded that production data could not be reproduced after optimization when a constant C:N ratio was assumed. Schartau and Oschlies (2003) also indicated that the parameter optimization of a Redfield NPZD model with photo-acclimation leads to high value of the parameter $\alpha$ (initial PI slope) "likely [to] compensat[e] for a deficiency in the parameterization of light-limited growth." 
Finally, Oschlies and Schartau (2005) concluded that their model was unable to reproduce the observed data after optimization due "both to errors in the physical model component and to errors in the structure of the ecosystem model, which an objective estimation of ecosystem model parameters by data assimilation alone cannot resolve." Besides, the stoichiometry of total particulate organic matter is known to be non-Redfield at BATS (Michaels and Knap, 1996; Cotner et al., 1997), as already reported in other parts of the North Atlantic (Sambrotto et al., 1993; Kortzinger et al., 2001). Surface and mixed layer values of the C:N ratio of particulate organic matter recorded at BATS in 1998 vary from 6.19 to 10.26 molC.mol $N^{-1}$, with values larger than $8 \mathrm{molC} \cdot \mathrm{mol}^{-1}$ from June to August (Fig. 7). However, the comparison of these observed values with simulated C:N ratios of production and phytoplankton are not straightforward, since the proportions of phytoplanktonic nitrogen and carbon relative to total particulate organic nitrogen and carbon are unknown. Nevertheless, the increase of C:N ratios during oligotrophic conditions is well reproduced by the cell quota formulations, because of low nutrient availability during the summer. For cell-quota formulations, it is then the ability of the C:N ratio to vary under changing environmental conditions (flexibility) that is responsible to a more realistic simulated production.

Similarly, an in situ study of the evolution of the C:N ratios of particulate organic matter and production in the mixed layer in the North-East Atlantic indicated that these C:N ratios were higher during summer than during spring, with values of C:N ratio of production of 10-16 and 5-6 molC.mol $\mathrm{N}^{-1}$, respectively (Kortzinger et al., 2001). These results suggest that our conclu- 
sions at BATS may extend to other areas in the ocean. Besides, it would be interesting to adapt this study to a station where data of phytoplanktonic nitrogen and carbon would be available in order to discriminate between the different quota formulations (P2.5, P3.0, and GP3.0).

\subsection{Implications for marine ecosystem modelling}

Several recent studies, that have compared different biogeochemical models, have focused on the structure of the model rather than on the formulation of phytoplankton growth (Friedrichs et al., 2006, 2007; Ward et al., 2010; Kriest et al., 2010; Bagniewski et al., 2011). Friedrichs et al. (2006) found that a change in the physical model had a more important impact than a change in the ecosystem model complexity. Similarly, Kriest et al. (2010) demonstrated that increasing complexity of a simple biogeochemical model at global scale did not necessarily improve the model's performance. Nevertheless, the choice of model complexity (food web structure, description of key physiological processes, parameter estimations, plankton functional types) is one of the challenges of future marine ecosystem modelling (Flynn, 2003a; Le Quéré et al., 2005; Flynn, 2010; Anderson, 2010; Allen and Fulton, 2010; Allen and Polimene, 2011). Besides, the use of complex models is still under debate because of our lack of specific knowledge in parameterizing plankton physiology and its variability (Anderson, 2005; Allen et al., 2010; Allen and Polimene, 2011).

Our study allows to quantify the error made when a constant Redfield stoichiometry is considered (instead of a variable C:N ratio) in phytoplankton growth formulation, as it is still the case in most biogeochemical models, especially when they are used at global scale. Indeed, only a few global 
ecosystem models decouple nitrogen and carbon dynamics (Vichi et al., 2007; Vichi and Masina, 2009). A recent study using a marine ecosystem model at global scale decoupled nitrogen and phosphorus dynamics relative to carbon, but still used a Monod-type version of nutrient limitation (Tagliabue et al., 2011). This model was thus "in between" Monod-Redfield and cell quota formulations. Global scale models that decouple carbon and nitrogen uptakes are particularly needed to study the impact of increased $\mathrm{CO}_{2}$ in the ocean. Indeed, carbon dioxide enhances carbon fixation but not dissolved inorganic nitrogen uptake, thus potentially increasing C:N ratios. Such processes have already been observed in mesocosm experiments (Riebesell et al., 2007), and should now be incorporated in global marine ecosystem models. Besides, climate change will likely modify to some degree the stoichiometry of inorganic and organic C:N:P in the oceans (Hutchins et al., 2009). For these reasons, models without enough 'flexibility' in their formulation will not be able to represent the non-linearities between carbon and nitrogen assimilation. In parallel with model improvements, field and in situ experiments should continue in collaboration with modelers to increase our knowledge in plankton physiology and dynamics under varying environment and provide data to calibrate and validate models.

\section{Conclusion}

The aim of the present work was to assess the advantages of taking into account photo-acclimation and variable stoichiometry of the phytoplankton growth in marine ecosystem models. After parameter calibration through an optimization procedure, lower misfits with observed data at BATS were 
simulated when photo-acclimation and non-Redfield stoichiometry were considered (i.e., variable $\mathrm{Chl}$ : $\mathrm{C}$ and $\mathrm{C}: \mathrm{N}$ ratios). The main differences in qualitative and quantitative behaviours of phytoplankton growth models were observed under oligotrophic conditions, because of the lack of model flexibility. In agreement with previous studies, photo-acclimation was mandatory to simultaneously reproduce the observed deep chlorophyll maximum and subsurface production during oligotrophic conditions. Moreover, quota formulations enabled a better agreement with production data in subsurface and during oligotrophic conditions than Redfield formulations. No clear difference was detected between quota formulations with diagnostic or prognostic chlorophyll, and more data would be needed to discriminate between these quota formulations with photo-acclimation. Future work would embed these different phytoplankton growth formulations within a 3D physical model to test whether our results can be generalized under contrasted oceanic regime and at basin scale (Ayata et al., in prep.).

\section{Acknowledgements}

This work was supported by the Action Collaborative de Recherche NAUTILUS funded by the french Institut National de la Recherche en Informatique et en Automatisme (INRIA) and is part of the TANGGO initiative supported by the CNRS-INSU-LEFE program. SDA was supported by a post-doctoral fellowship from INRIA. The authors would like to thank Kevin Flynn and an anonymous reviewer for their constructive comments on a first version of this manuscript. 


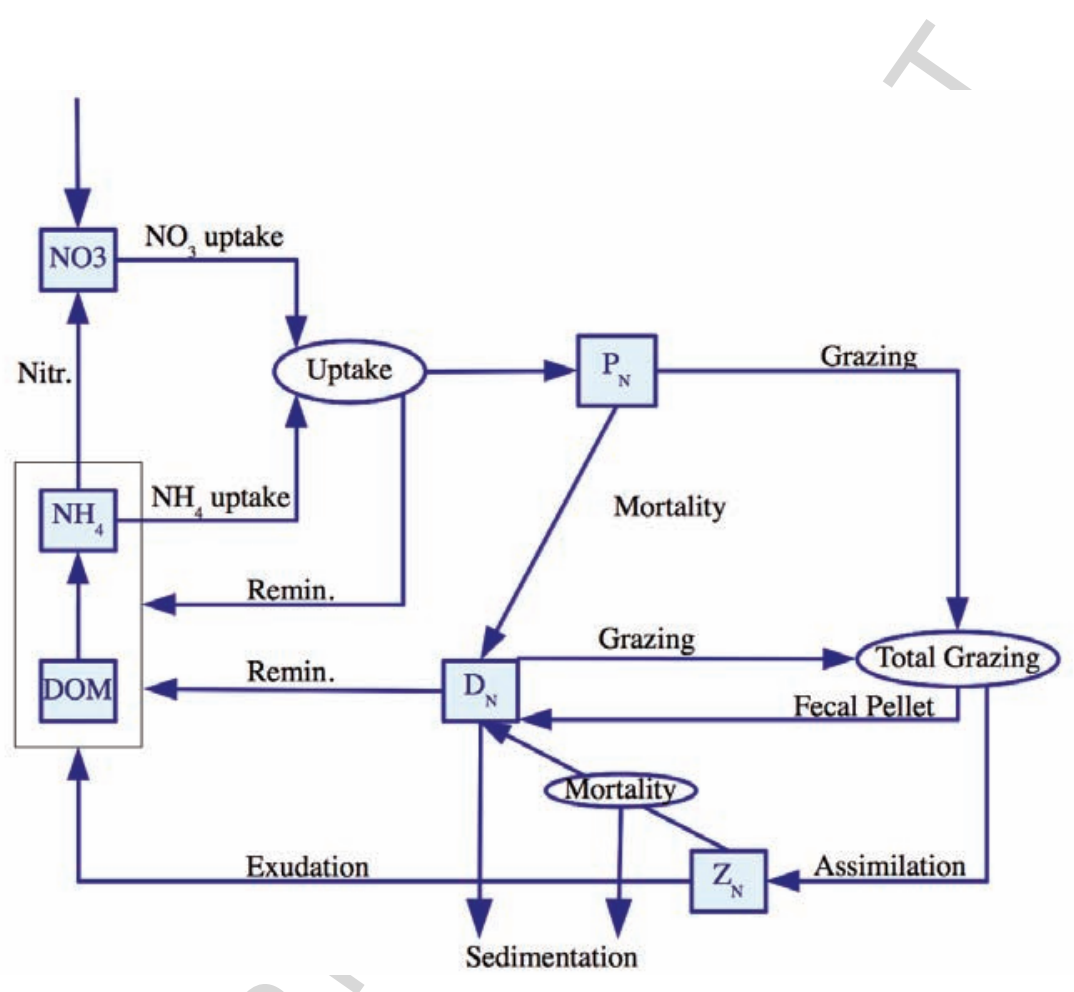

Figure 1: Structure of the LOBSTER marine ecosystem model. The six state variables are in nitrogen currency (blue color). The detailed equations of the model are given in Table 1. Nitr.: Nitrification; Remin.: Remineralization. 
A) P1.0

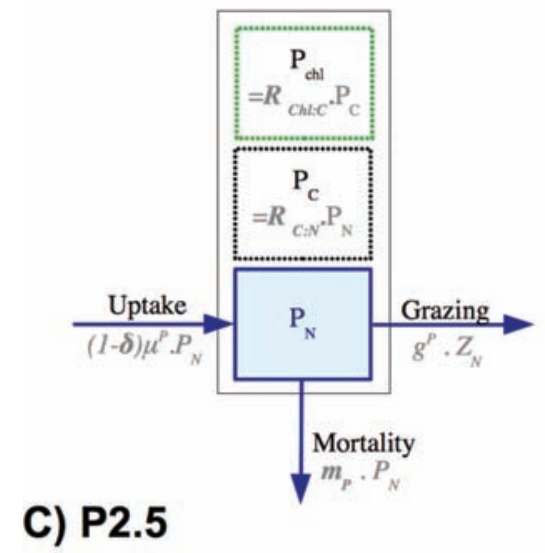

B) P1.5
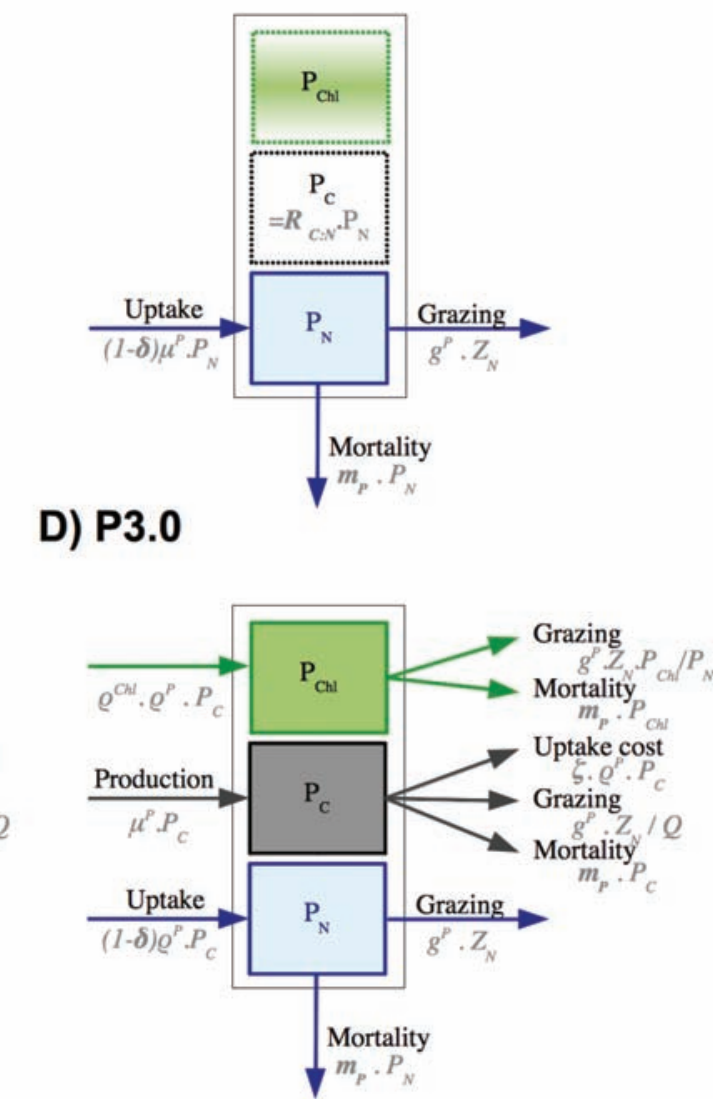

Figure 2: Structure of the phytoplankton growth formulations: A) Redfield formulation with constant chlorophyll:carbon ratio (P1.0), B) Redfield formulation with diagnostic chlorophyll (P1.5), C) quota formulation with diagnostic chlorophyll (P2.5), and D) quota formulation with prognostic chlorophyll (P3.0). Note that the Geider formulation (GP3.0) shares the same structure as P3.0. State variables are in plain color and diagnostic variables in shaded color. The colors of the variables indicate their currency: blue for nitrogen, grey for carbon, and green for chlorophyll. 
Figure 3: Taylor and target diagrams of the monthly vertical profiles of nitrate concentration (diamonds), PON concentration (triangles), chlorophyll concentration (circle) and primary production (square) calculated for each formulation with default parameters (empty symbol) and after optimization (full symbol). The Taylor diagram represents in polar coordinates the normalized standard deviation and the correlation between observation and model output. On this diagram, the distance with the point of coordinates $(1,0)$ measures the normalized root mean squared differences between observation and model output.
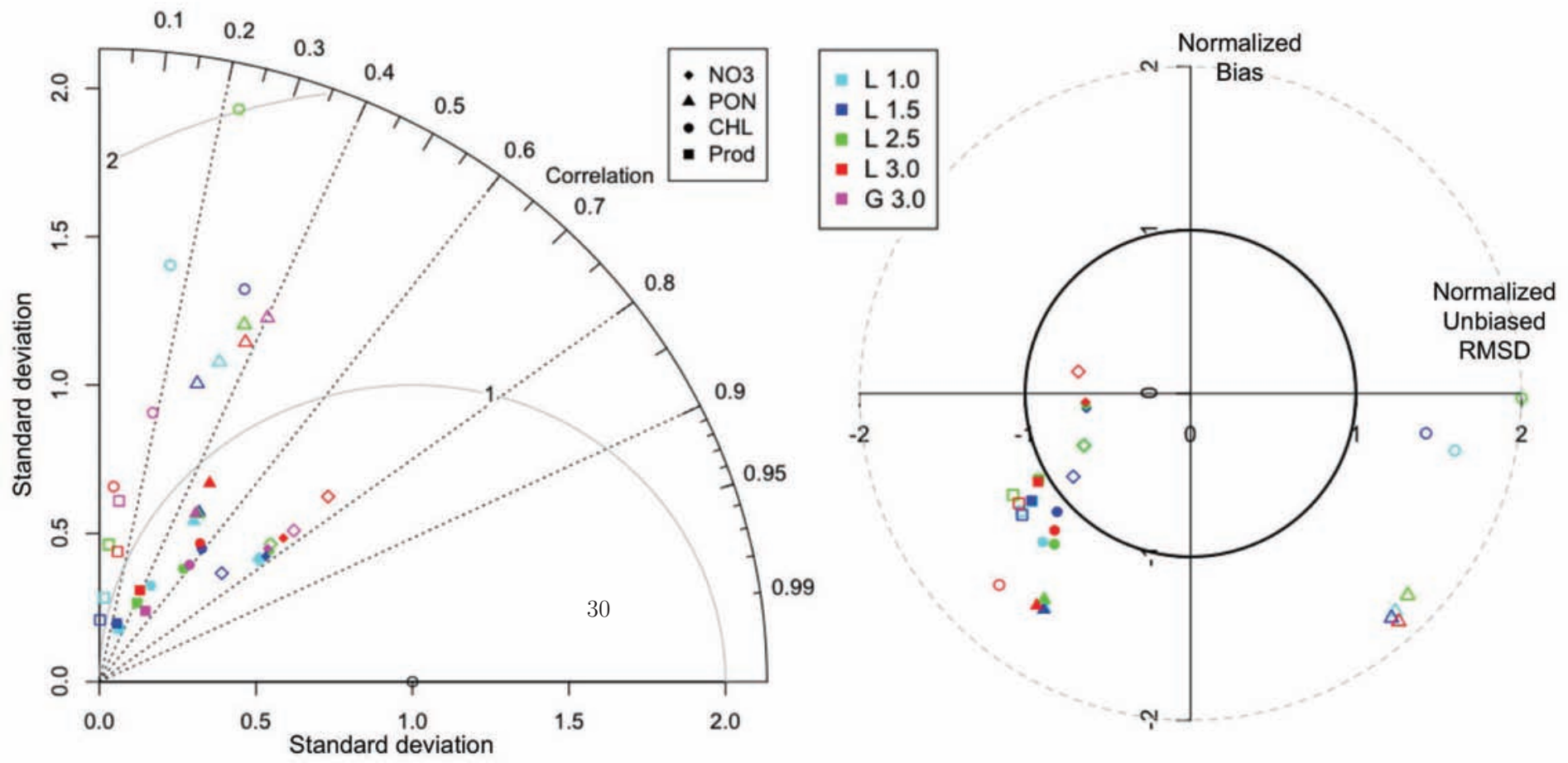
Figure 4: Seasonal cycles of nitrate, particulate organic nitrogen (PON), chlorophyll, and primary production at BATS in 1998, simulated with the different models after optimization and observed at BATS in 1998. The observed mixed layer depth is superimposed in white over the observed nitrate profiles.

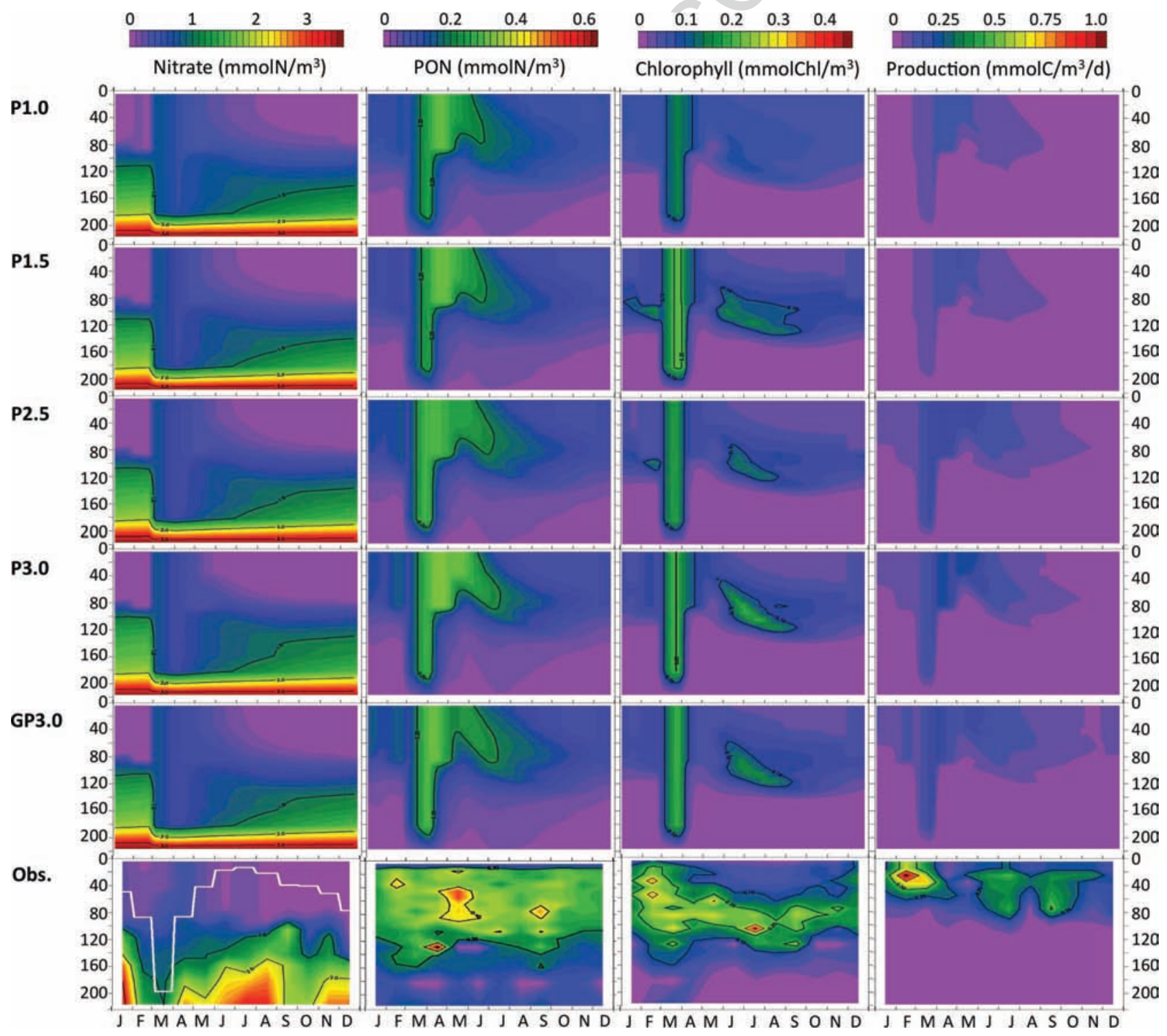


Figure 5: Average vertical profiles during boom (Mar-Apr) and during oligotrophic conditions (Jul-Aug) of the concentrations of phytoplanktonic nitrogen, phytoplanktonic carbon, C/ N ratio and C:Chl ratio, simulated with P1.0 (dark blue), P1.5 (light blue), P2.5 (green), P3.0 (red), and GP3.0 (magenta) after optimization.

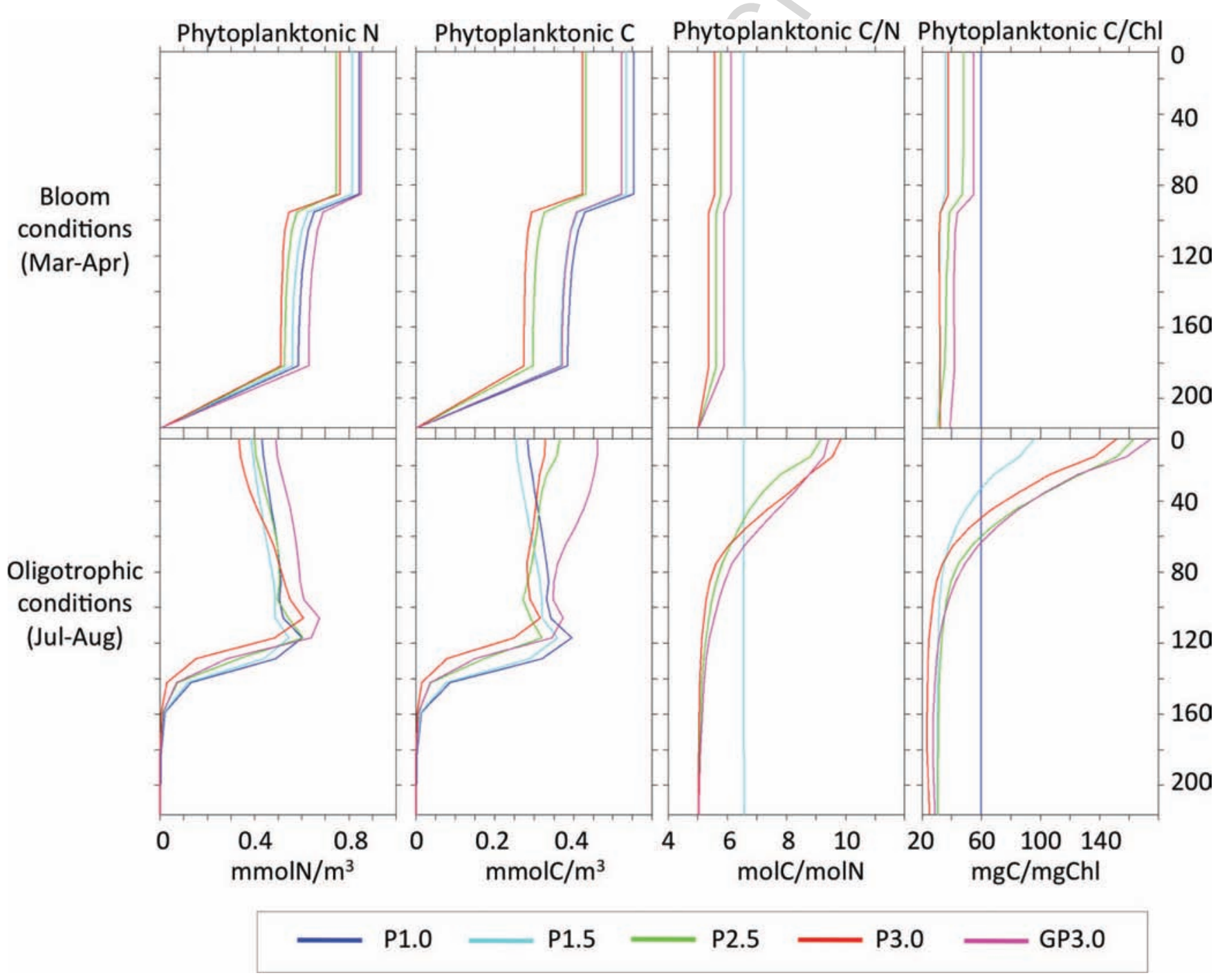


Figure 6: Temporal evolution of integrated daily production in carbon and in nitrogen from 0 to $234 \mathrm{~m}$, simulated by the Redfield formulations P1.0 (blue) and P1.5 (light blue), and by the quota formulations P2.5 (green), P3.0 (red), and GP3.0 (magenta) after optimization. The observed values of the integrated daily production in carbon at BATS are indicated (black crosses).

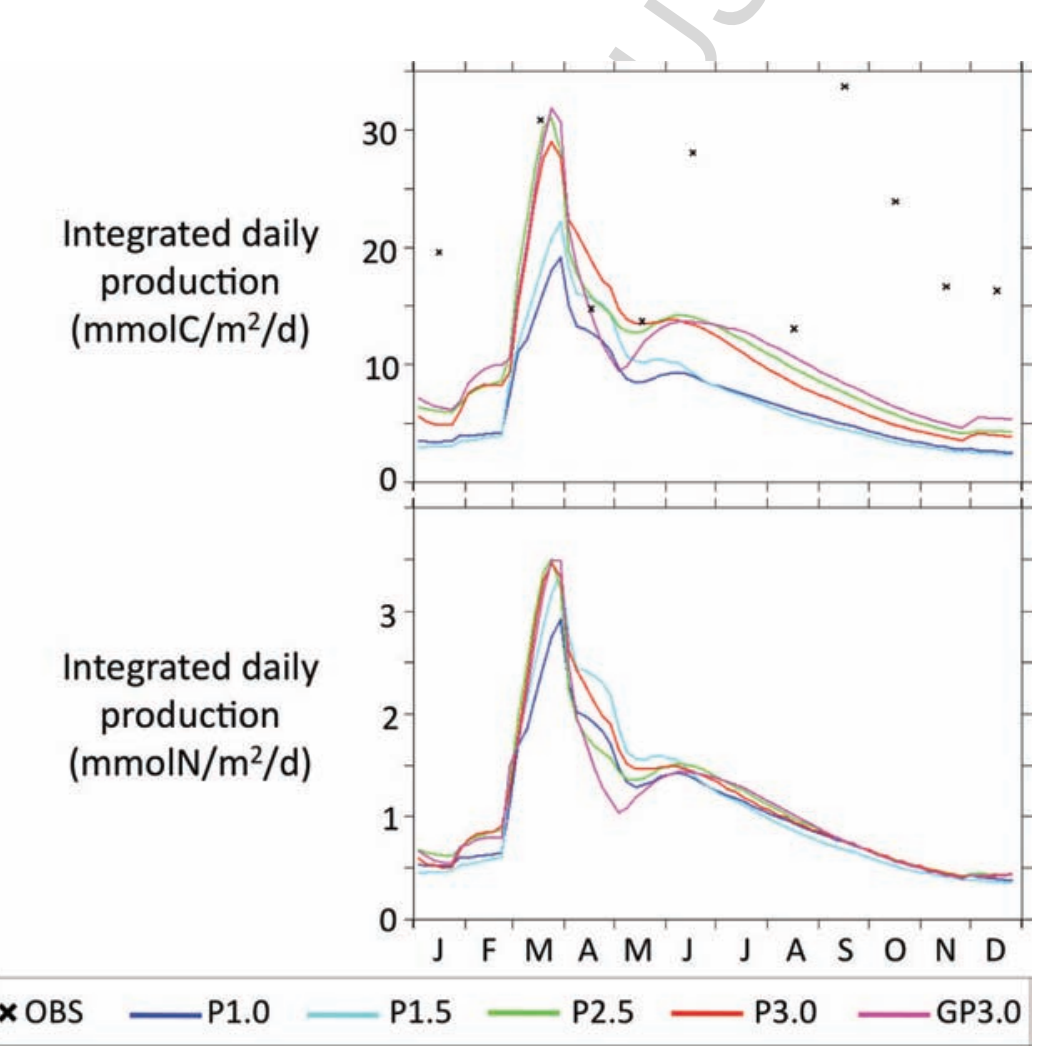


Figure 7: Temporal evolution of the C:N ratio of the production and of the phytoplankton at 0-10 m, 40-50 $\mathrm{m}$ and 90-100 $\mathrm{m}$ after optimization, simulated by the Redfield formulations P1.0 and P1.5 (light blue), and by the quota formulations P2.5 (green), P3.0 (red), and GP3.0 (magenta). The C:N ratio of the production is calculated as the ratio between the total production in carbon and the total production in nitrogen. The observed surface values of the C:N ratio of the total particulate organic matter measured at BATS in 1998 are superimposed on the simulated C:N ratio of the phytoplankton (black crosses).

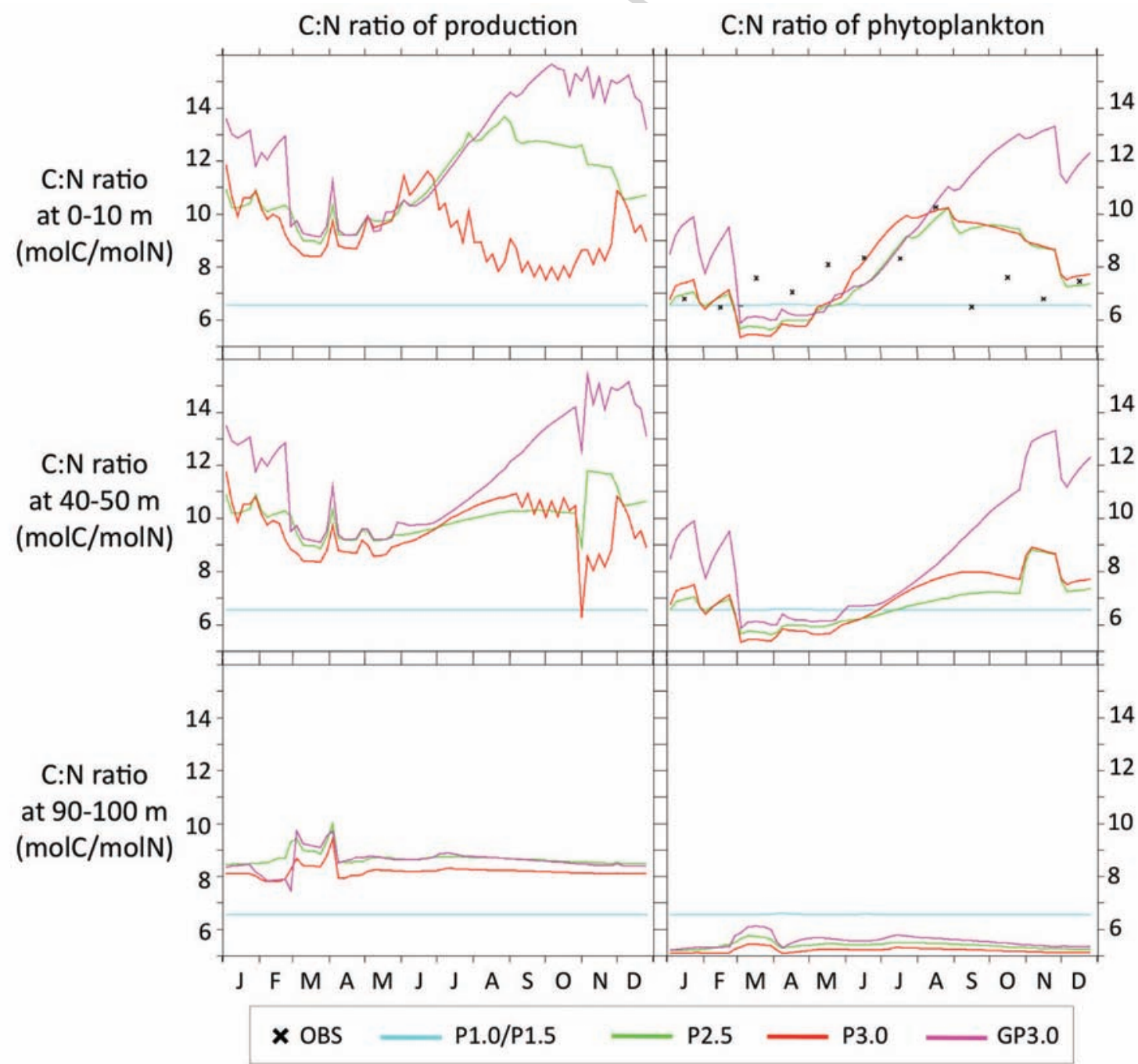


Table 1: Equations of the LOBSTER marine ecosystem model. The source minus sink (sms) terms of the equations are given for each of the six state variables of the model (in nitrogen currency): nitrate $\left(\mathrm{NO}_{3}\right)$, ammonium $\left(\mathrm{NH}_{4}\right)$, phytoplankton $\left(\mathrm{P}_{N}\right)$, zooplankton $\left(\mathrm{Z}_{N}\right)$, detritus $\left(\mathrm{D}_{N}\right)$, and dissolved organic matter (DOM). The phytoplankton growth formulation is a Redfield formulation with constant Chl:C ratio (P1.0 formulation). The definition of the parameters and their default values are presented in Table 2.

\begin{tabular}{ll}
\hline Definition & Equation \\
\hline
\end{tabular}

Nitrate source minus sink $\operatorname{sms}\left(\mathrm{NO}_{3}\right)=\lambda_{\mathrm{NH}_{4}} \cdot \mathrm{NH}_{4}-\frac{L_{N O_{3}}}{L_{N}}$.uptake

Ammonium source minus sink $\operatorname{sms}\left(\mathrm{NH}_{4}\right)=-\lambda_{\mathrm{NH}_{4}} \cdot \mathrm{NH}_{4}-\frac{L_{N H_{4}}}{L_{N}}$.uptake $+\lambda_{D O M} \cdot D O M$ $+f_{n} \cdot\left(\right.$ d.uptake $\left.+\lambda_{Z} \cdot Z_{N}+\lambda_{D} \cdot D_{N}\right)$

¿ Phytoplankton source minus sink $\operatorname{sms}\left(P_{N}\right)=(1-\delta) \cdot$ uptake $-G_{P}-m_{P} \cdot P_{N}$

Zooplankton source minus sink $\operatorname{sms}\left(Z_{N}\right)=a_{Z} \cdot\left(G_{P}+G_{D}\right)-m_{Z} \cdot Z_{N}^{2}-\lambda_{Z} \cdot Z_{N}$

Detritus source minus sink $\operatorname{sms}\left(D_{N}\right)=m_{P} \cdot P_{N}+f_{Z} \cdot m_{Z} \cdot Z_{N}^{2}+\left(1-a_{Z}\right) \cdot\left(G_{P}+G_{D}\right)-G_{D}-\lambda_{D} \cdot D_{N}-w_{D}$ DOM source minus sink $\operatorname{sms}(D O M)=\left(1-f_{n}\right) \cdot\left(\delta . u p t a k e+\lambda_{Z} \cdot Z_{N}+\lambda_{D} \cdot D_{N}\right)-\lambda_{D O M} \cdot D O M$

Nitrogen uptake uptake $=\mu_{m} \cdot L_{N} \cdot L_{I} \cdot P_{N}$

Light limitation

$L_{I}=\left[1-e^{\left(-\frac{\alpha \cdot R_{C h l: C \cdot P A R}}{\mu_{m}}\right)}\right]$

Nutrient limitation

$L_{N}=L_{N O_{3}}+L_{N H_{4}}$

Nitrate limitation

$L_{N O_{3}}=\frac{N_{3}}{K_{N O_{3}}+N O_{3}} \cdot e^{-\psi \cdot N H_{4}}$

Ammonium limitation

$L_{N_{4}}=\frac{N_{4}}{K_{N H_{4}}+N_{4}}$

Grazing on phytoplankton

Grazing on detritus $G_{P}=g \cdot \frac{p \cdot P_{N}}{K_{g}+p \cdot P_{N}+(1-p) \cdot D_{N}} \cdot Z_{N}$

$G_{D}=g \cdot \frac{(1-p) \cdot D_{N}}{K_{g}+p \cdot P_{N}+(1-p) \cdot D_{N}} \cdot Z_{N}$

Grazing preference for phytoplankton $\quad p=\frac{\tilde{p} \cdot P_{N}}{\tilde{p} \cdot P_{N}+(1-\tilde{p}) \cdot D_{N}}$ 
Table 2: Parameters of the LOBSTER model, with default values from previous studies (Lévy et al., 2005; Kremeur et al., 2009).

\begin{tabular}{|c|c|c|c|}
\hline Symbol & Definition & Value & Unit \\
\hline \multicolumn{4}{|c|}{ Nutrient-related parameters } \\
\hline$K_{\mathrm{NO}_{3}}$ & $\mathrm{NO}_{3}$ half saturation constant & 0.7 e- 6 & mmolN.m $m^{-3}$ \\
\hline$K_{\mathrm{NH}_{4}}$ & $\mathrm{NH}_{4}$ half saturation constant & $0.001 \mathrm{e}-6$ & mmolN.m $\mathrm{m}^{-3}$ \\
\hline$\psi$ & Inhibition of $\mathrm{NO}_{3}$ uptake by $\mathrm{NH}_{4}$ & & unitless \\
\hline$\lambda_{N H_{4}}$ & $\mathrm{NH}_{4}$ nitrification rate & 0.05 & $d^{-1}$ \\
\hline \multicolumn{4}{|c|}{ Phytoplankton growth and death } \\
\hline$\alpha$ & Photosynthesis-irradiance (PI) initial slope & 1.82 & $\mathrm{~d}^{-1} \cdot \mathrm{W}^{-1} \cdot \mathrm{m}^{2} \cdot \mathrm{gC} \cdot \mathrm{gChl}^{-1}$ \\
\hline$\mu_{m}$ & Maximal growth rate of phytoplankton & 1 & $d^{-1}$ \\
\hline$\delta$ & Excretion ratio of phytoplankton & 0.05 & unitless \\
\hline$m_{P}$ & Phytoplankton mortality rate & 0.05 & $d^{-1}$ \\
\hline \multicolumn{4}{|c|}{ Zooplankton grazing and mortality } \\
\hline$K_{g}$ & Grazing half saturation constant & 1 e-6 & mmolN.m ${ }^{-3}$ \\
\hline$g$ & Maximal zooplankton grazing rate & 0.8 & $d^{-1}$ \\
\hline$a_{Z}$ & Assimilated food fraction & 0.7 & unitless \\
\hline$\lambda_{Z}$ & Exsudation rate of zooplankton & 0.07 & $\mathrm{~d}^{-1}$ \\
\hline$m_{Z}$ & Zooplankton mortality rate & $0.12 \mathrm{e}+6$ & $\mathrm{~d}^{-1} \cdot \mathrm{mmolN}^{-1} \cdot \mathrm{m}^{3}$ \\
\hline$\tilde{p}$ & Zooplankton preference for detritus & 0.8 & unitless \\
\hline$f_{Z}$ & Fraction of slow sinking mortality & 0.5 & unitless \\
\hline \multicolumn{4}{|c|}{ Remineralization } \\
\hline$\lambda_{D O M}$ & Remineralization rate of DOM & 0.006 & $d^{-1}$ \\
\hline$f_{n}$ & $\mathrm{NH}_{4} / \mathrm{DOM}$ redistribution ratio & 0.75 & unitless \\
\hline$w_{D}$ & Detritus sedimentation speed & 3 & $\mathrm{~m} \cdot \mathrm{d}^{-1}$ \\
\hline$\lambda_{D}$ & Remineralization rate of detritus & 0.05 & $d^{-1}$ \\
\hline
\end{tabular}


Table 4: Equations of the different phytoplankton growth formulations. P1.0: Redfield formulation with constant Chl:C ratio. P1.5: Redfield formulation with diagnostic Chl:C ratio. P2.5: Cell-quota formulation with diagnostic Chl:C ratio. P3.0/GP3.0: Cell-quota formulation with prognostic Chl:C ratio. The definition of the parameters and their default values are presented in Tables 2 and 5. Source minus sink functions $(s m s)$ are only for prognostic variables (in bold).

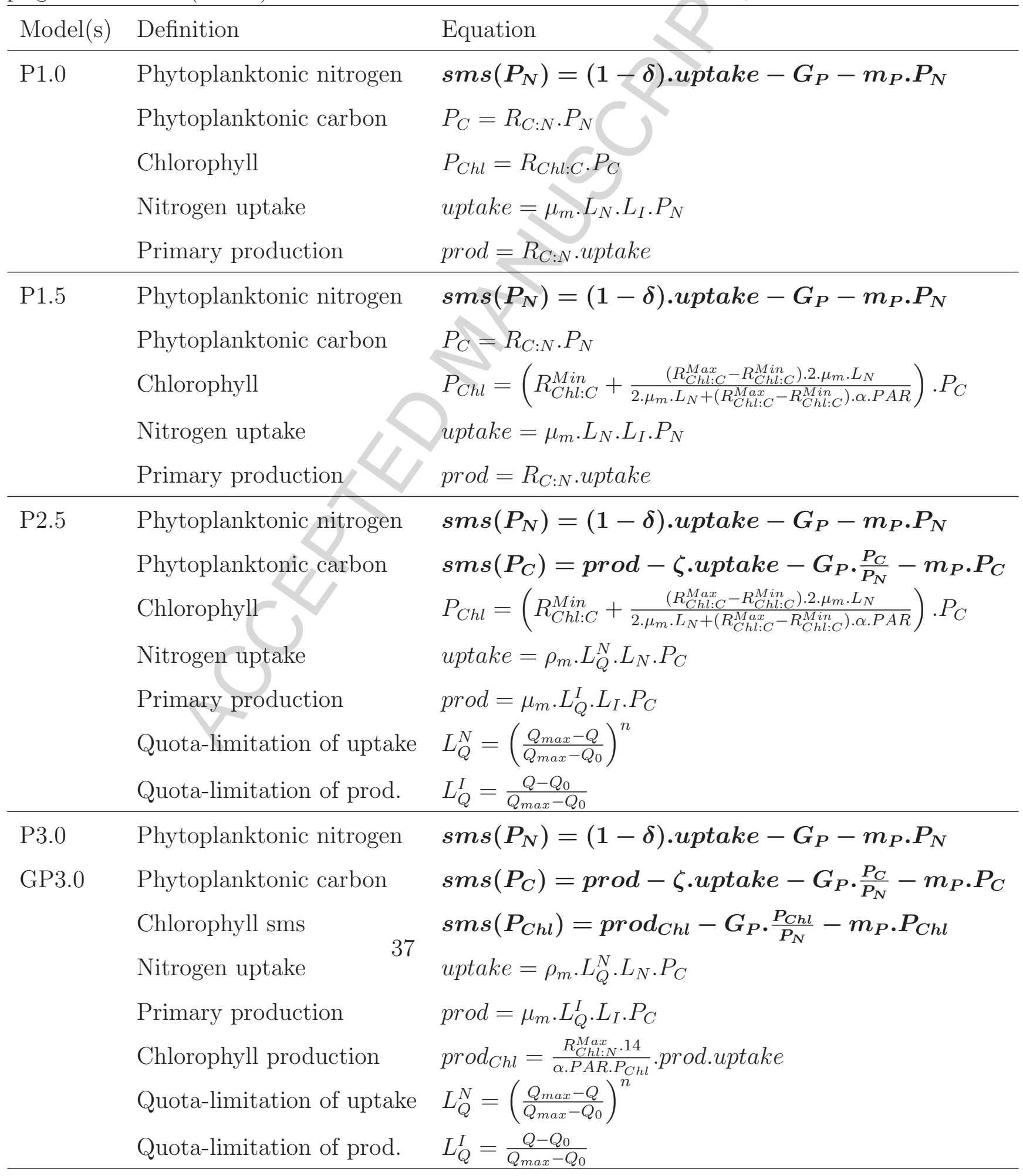


Table 5: Parameters of the different phytoplankton growth formulations and associated default values from Geider et al. (1998).

\begin{tabular}{|c|c|c|c|c|}
\hline Symbol & Definition & Defaul & Unit & Models \\
\hline \multicolumn{5}{|c|}{ Constant ratios } \\
\hline$R_{C h l: C}$ & Chlorophyll:Carbon ratio & $1 / 60$ & $\mathrm{gChl}_{\mathrm{gC}} \mathrm{gC}^{-1}$ & $\mathrm{P} 1.0$ \\
\hline$R_{C: N}$ & Phytoplankton C:N Redfield ratio & 6.56 & molC.molN ${ }^{-1}$ & P1.0 P1.5 \\
\hline \multicolumn{5}{|c|}{ Diagnostic chlorophyll } \\
\hline$R_{C h l: C}^{M i n}$ & Minimum Chl:C ratio & $1 / 200$ & mgChl.mmolC ${ }^{-1}$ & $\mathrm{P} 1.5 \mathrm{P} 2.5$ \\
\hline$R_{C h l: C}^{M a x}$ & Maximum Chl:C ratio & $1 / 30$ & mgChl.mmolC ${ }^{-1}$ & P1.5 P2.5 \\
\hline \multicolumn{5}{|c|}{ Nutrient uptake } \\
\hline$\rho_{m}$ & Maximum uptake rate & 0.2 & $\operatorname{molN} \cdot \operatorname{mol} C^{-1} \cdot d^{-1}$ & P2.5 P3.0 \\
\hline & (defined by $\rho_{m}=\mu_{m} \cdot Q_{\max }$ ) & & & \\
\hline$\zeta$ & Cost of nitrogen assimilation & 3 & mol C.mol N ${ }^{-1}$ & P2.5 P3.0 \\
\hline \multicolumn{5}{|c|}{ Phytoplanktonic cell quotas } \\
\hline$Q_{0}$ & Minimum value of $Q$ & $1 / 20$ & mol N.mol C ${ }^{-1}$ & P2.5 P3.0 \\
\hline$Q_{\max }$ & Maximum value of $Q$ & $1 / 5$ & mol N.mol C ${ }^{-1}$ & P2.5 P3.0 \\
\hline$n$ & Shape factor & 1 & - & P2.5 P3.0 \\
\hline \multicolumn{5}{|c|}{ Chlorophyll synthesis } \\
\hline$R_{C h l: N}^{M a x}$ & Maximum Chl:N ratio & 2 & gChl.gN $N^{-1}$ & P3.0 \\
\hline
\end{tabular}


Table 7: Parameter range allowed for optimization. Each parameter was binary coded on 6 bits (and had then 64 possible values).

\begin{tabular}{cccc}
\hline Parameter & Lower bound & Upper bound & Increment \\
\hline$\alpha$ & 0.3 & 12.9 & 0.2 \\
$\mu_{m}$ & 0.1 & 6.4 & 0.1 \\
$K_{g}$ & $1.0 \mathrm{e}-7$ & $32.5 \mathrm{e}-7$ & $0.5 \mathrm{e}-7$ \\
$g$ & 0.1 & 6.4 & 0.1 \\
$\zeta$ & 1.00 & 4.15 & 0.05 \\
$R_{\text {Chl:N }}^{\text {Max }}$ & 0.1 & 6.4 & 0.1 \\
\hline
\end{tabular}

Table 8: Optimized parameters and associated cost functions $(F)$.

\begin{tabular}{|c|c|c|c|c|c|c|}
\hline \multirow[t]{2}{*}{ Parameter } & \multirow{2}{*}{ Default values } & \multicolumn{5}{|c|}{ Optimized values } \\
\hline & & P1.0 & $\mathrm{P} 1.5$ & P2.5 & P3.0 & GP3.0 \\
\hline$\alpha$ & 1.82 & 1.7 & 1.1 & 2.3 & 1.7 & 2.1 \\
\hline$\mu_{m}$ & 1 & 0.3 & 0.6 & 1.0 & 1.7 & 0.6 \\
\hline$K_{g}$ & $10.0 \mathrm{e}-7$ & $23.0 \mathrm{e}-7$ & $18.0 \mathrm{e}-7$ & $22.5 \mathrm{e}-7$ & $23.0 \mathrm{e}-7$ & $26.0 \mathrm{e}-7$ \\
\hline$g$ & 0.8 & 5.0 & 4.2 & 5.1 & 5.3 & 5.1 \\
\hline$\zeta$ & 3.00 & - & - & 3.52 & 3.24 & 3.36 \\
\hline$R_{C h l: N}^{M a x}$ & 3 & - & - & - & 6.4 & 5.6 \\
\hline \multicolumn{2}{|c|}{$F$ after optimization } & 0.855 & 0.823 & 0.790 & 0.802 & 0.773 \\
\hline \multicolumn{2}{|c|}{$F$ with default value } & 1.118 & 1.217 & 1.1217 & 1.120 & 1.052 \\
\hline
\end{tabular}


Table 9: Total productions, new production, and f-ratio (new production/total production in nitrogen) simulated at BATS in 1998 after optimization.

Annual values

\begin{tabular}{ccccc}
\hline Model & $\begin{array}{c}\text { Total Production } \\
\left(\mathrm{mol} C / \mathrm{m}^{2}\right)\end{array}$ & $\begin{array}{c}\text { Total Production } \\
\left(\mathrm{molN} / \mathrm{m}^{2}\right)\end{array}$ & $\begin{array}{c}\text { New Production } \\
\left(\mathrm{molN} / \mathrm{m}^{2}\right)\end{array}$ & f-ratio \\
\hline P1.0 & 2.495 & 0.380 & 0.126 & 0.33 \\
P1.5 & 2.647 & 0.403 & 0.133 & 0.33 \\
P2.5 & 3.903 & 0.415 & 0.163 & 0.39 \\
P3.0 & 3.728 & 0.421 & 0.134 & 0.32 \\
GP3.0 & 3.970 & 0.399 & 0.135 & 0.34 \\
\hline
\end{tabular}

Bloom period (Mars to April)

\begin{tabular}{ccccc}
\hline Model & $\begin{array}{c}\text { Total Production } \\
\left(\mathrm{mol} C / \mathrm{m}^{2}\right)\end{array}$ & $\begin{array}{c}\text { Total Production } \\
\left(\mathrm{molN} / \mathrm{m}^{2}\right)\end{array}$ & $\begin{array}{c}\text { New Production } \\
\left(\mathrm{molN} / \mathrm{m}^{2}\right)\end{array}$ & f-ratio \\
\hline P1.0 & 0.855 & 0.130 & 0.064 & 0.49 \\
P1.5 & 1.014 & 0.154 & 0.076 & 0.49 \\
P2.5 & 1.292 & 0.143 & 0.062 & 0.43 \\
P3.0 & 1.309 & 0.153 & 0.073 & 0.48 \\
GP3.0 & 1.240 & 0.136 & 0.066 & 0.48 \\
\hline
\end{tabular}

Oligotrophic period (July to August)

\begin{tabular}{ccccc}
\hline Model & $\begin{array}{c}\text { Total Production } \\
\left(\mathrm{molC} / \mathrm{m}^{2}\right)\end{array}$ & $\begin{array}{c}\text { Total Production } \\
\left(\mathrm{molN} / \mathrm{m}^{2}\right)\end{array}$ & $\begin{array}{c}\text { New Production } \\
\left(\mathrm{molN} / \mathrm{m}^{2}\right)\end{array}$ & f-ratio \\
\hline P1.0 & 0.424 & 0.064 & 0.016 & 0.25 \\
P1.5 & 0.403 & 0.061 & 0.012 & 0.20 \\
P2.5 & 0.678 & 0.069 & 0.017 & 0.25 \\
P3.0 & 0.605 & 0.066 & 0.013 & 0.20 \\
GP3.0 & 0.725 & 0.071 & 0.019 & 0.27 \\
\hline
\end{tabular}




\section{References}

Allen, J., Somerfield, P., Siddorn, J., 2002. Primary and bacterial production in the mediterranean sea: a modelling study. Journal of Marine Systems 33-34, 473-495.

Allen, J.I., Aiken, J., Anderson, T.R., Buitenhuis, E., Cornell, S., Geider, R.J., Haines, K., Hirata, T., Holt, J., Le Quéré, C., Hardman-Mountford, N., Ross, O.N., Sinha, B., While, J., 2010. Marine ecosystem models for earth systems applications: The marQUEST experience. J. Mar. Sys. 81, 19-33. Symposium on Advances in Marine Ecosystem Modelling Research, Plymouth, England, Jun 23-26, 2008.

Allen, J.I., Fulton, E.A., 2010. Top-down, bottom-up or middle-out? avoiding extraneous detail and over-generality in marine ecosystem models. Prog. Oceanogr. 84, 129-133.

Allen, J.I., Polimene, L., 2011. Linking physiology to ecology: towards a new generation of plankton models. J. Plankton Res. 33, 989-997.

Anderson, T., 2005. Plankton functional type modelling: running before we can walk? J. Plankton Res. 27, 1073-1081.

Anderson, T.R., 2010. Progress in marine ecosystem modelling and the "unreasonable effectiveness of mathematics". J. Mar. Sys. 81, 4-11. Symposium on Advances in Marine Ecosystem Modelling Research, Plymouth, England, Jun 23-26, 2008.

Aumont, O., Bopp, L., 2006. Globalizing results from ocean in situ iron fertilization studies. Global Biogeochemical Cycles 20(2), doi:10.1029/2005GB002591. 
Ayata, S.D., Lévy, M., Aumont, O., Resplandy, L., Tagliabue, A., Sciandra, A., Bernard, O., . Variable phytoplanktonic c:n ratio decreases the variability of primary production in the oceancompared to redfield formulation. in prep. .

Bagniewski, W., Fennel, K., Perry, M.J., D’Asaro, E.A., 2011. Optimizing models of the North Atlantic spring bloom using physical, chemical and bio-optical observations from a Lagrangian float. Biogeosciences 8, 1291-1307.

Baklouti, M., Diaz, F., Pinazo, C., Faure, V., Queguiner, B., 2006. Investigation of mechanistic formulations depicting phytoplankton dynamics for models of marine pelagic ecosystems and description of a new model. Prog. Oceanogr. 71, $1-33$.

Baumert, H.Z., Petzoldt, T., 2008. The role of temperature, cellular quota and nutrient concentrations for photosynthesis, growth and light-dark acclimation in phytoplankton. Limnologica 38, 313-326.

Bernard, O., 2011. Hurdles and challenges for modelling and control of microalgae for CO2 mitigation and biofuel production. J. Process Contr. 21, 1378-1389.

Bissett, W., Walsh, J., Dieterle, D., Carder, K., 1999. Carbon cycling in the upper waters of the Sargasso Sea: I. numerical simulation of differential carbon and nitrogen fluxes. Deep-Sea Research I 46, 205-269.

Blackford, J., Allen, J., Gilbert, F., 2004. Ecosystem dynamics at six contrasting sites: a generic modelling study. J. Mar. Sys. 52, 191-215.

Bougaran, G., Bernard, O., Sciandra, A., 2010. Modeling continuous cultures of microalgae colimited by nitrogen and phosphorus. J. Theor. Biol. 265, 443-454.

Carroll, D., 1996. Chemical laser modeling with genetic algorithms. AIAA J. 34, $338-346$. 
Cloern, J., Grenz, C., Vidergar-Lucas, L., 1995. An empirical model of the phytoplankton chlorophyll:carbon ratio - the conversion factor between productivity and growth rate. Limnol. Oceanogr. 40, 1313-1321.

Cotner, J., Ammerman, J., Peele, E., Bentzen, E., 1997. Phosphorus-limited bacterioplankton growth in the Sargasso Sea. Aquat. Microb. Ecol. 13, 141149.

Dearman, J., Taylor, A., Davidson, K., 2003. Influence of autotroph model complexity on simulations of microbial communities in marine mesocosms. Mar. Ecol. Prog. Ser. 250, 13-28.

Doney, S., Glover, D., Najjar, R., 1996. A new coupled, one-dimensional biologicalphysical model for the upper ocean: Applications to the JGOFS Bermuda Atlantic time-series study (BATS) site. Deep-Sea Research I 43, 591-624.

Droop, M., 1968. Vitamin B12 and Marine Ecology. IV. The Kinetics of Uptake, Growth and Inhibition in Monochrysis lutheri. J. Mar. Biol. Assoc. UK 48, 689-733.

Droop, M., 1983. 25 years of algal growth kinetics: a personal view. Bot. Mar. 26, $99-112$.

Dutkiewicz, S., Follows, M.J., Bragg, J.G., 2009. Modeling the coupling of ocean ecology and biogeochemistry. Global Biogeochemical Cycles 23, doi:10.1029/2008GB003405.

Evans, G., 2003. Defining misfit between biogeochemical models and data sets. J. Mar. Sys. 40, 49-54. 33rd International Liege Colloquium on Ocean Dynamics, Liège, Belgium, May 07-11, 2001. 
Fasham, M., Ducklow, H., McKelvie, S., 1990. A nitrogen-based model of plankton dynamics in the ocean mixed layer. J. Mar. Res. 48, 591-639.

Faugeras, B., Bernard, O., Sciandra, A., Lévy, M., 2004. A mechanistic modelling and data assimilation approach to estimate the carbon/chlorophyll and carbon/nitrogen ratios in a coupled hydrodynamical-biological model. Non-Linear Proc. Geophys. 11, 515-533.

Faugeras, B., Lévy, M., Memery, L., Verron, J., Blum, J., Charpentier, I., 2003. Can biogeochemical fluxes be recovered from nitrate and chlorophyll data? A case study assimilating data in the Northwestern Mediterranean Sea at the JGOFS-DYFAMED station. J. Mar. Sys. 40, 99-125. 33rd International Liege Colloquium on Ocean Dynamics, Liège, Belgium, May 07-11, 2001.

Fennel, K., Losch, M., Schroter, J., Wenzel, M., 2001. Testing a marine ecosystem model: sensitivity analysis and parameter optimization. J. Mar. Sys. 28, 45-63.

Flynn, K., 2003a. Do we need complex mechanistic photoacclimation models for phytoplankton? Limnol. Oceanogr. 48, 2243-2249.

Flynn, K., 2003b. Modelling multi-nutrient interactions in phytoplankton; balancing simplicity and realism. Prog. Oceanogr. 56, 249-279.

Flynn, K., Flynn, K., 1998. The release of nitrite by marine dinoflagellatesdevelopment of a mathematical simulation. MARINE BIOLOGY 130, 455-470.

Flynn, K., Marshall, H., Geider, R., 2001. A comparison of two N-irradiance interaction models of phytoplankton growth. Limnol. Oceanogr. 46, 1794-1802.

Flynn, K.J., 2008. Use, abuse, misconceptions and insights from quota models the Droop cell quota model 40 years on. Oceanogr. Mar. Biol. 46, 1-23. 
Flynn, K.J., 2010. Ecological modelling in a sea of variable stoichiometry: Dysfunctionality and the legacy of Redfield and Monod. Prog. Oceanogr. 84, 52-65.

Follows, M.J., Dutkiewicz, S., Grant, S., Chisholm, S.W., 2007. Emergent biogeography of microbial communities in a model ocean. Science 315, 1843-1846.

Franks, P.J.S., 2009. Planktonic ecosystem models: perplexing parameterizations and a failure to fail. J. Plankton Res. 31, 1299-1306.

Friedrichs, M.A.M., Dusenberry, J.A., Anderson, L.A., Armstrong, R.A., Chai, F., Christian, J.R., Doney, S.C., Dunne, J., Fujii, M., Hood, R., McGillicuddy, Jr., D.J., Moore, J.K., Schartau, M., Spitz, Y.H., Wiggert, J.D., 2007. Assessment of skill and portability in regional marine biogeochemical models: Role of multiple planktonic groups. J. Geophys. Res.-Oceans 112.

Friedrichs, M.A.M., Hood, R.R., Wiggert, J.D., 2006. Ecosystem model complexity versus physical forcing: Quantification of their relative impact with assimilated Arabian Sea data. Deep-Sea Research I 53, 576-600.

Geider, R., MacIntyre, H., Kana, T., 1996. A dynamic model of photoadaptation in phytoplankton. Limnol. Oceanogr. 41, 1-15.

Geider, R., MacIntyre, H., Kana, T., 1998. A dynamic regulatory model of phytoplanktonic acclimation to light, nutrients, and temperature. Limnol. Oceanogr. 43, 679-694.

Geider, R., Platt, T., 1986. A mechanistic model of photoadaptation in microalgae. Mar. Ecol. Prog. Ser. 30, 85-92.

Hurtt, G., Armstrong, R., 1996. A pelagic ecosystem model calibrated with BATS data. Deep-Sea Research I 43, 653-683. 
Hurtt, G., Armstrong, R., 1999. A pelagic ecosystem model calibrated with BATS and OWSI data. Deep-Sea Research I 46, 27-61.

Hutchins, D.A., Mulholland, M.R., Fu, F., 2009. Nutrient Cycles and Marine Microbes in a CO2-Enriched Ocean. Oceanography 22, 128-145.

Jolliff, J.K., Kindle, J.C., Shulman, I., Penta, B., Friedrichs, M.A.M., Helber, R., Arnone, R.A., 2009. Summary diagrams for coupled hydrodynamic-ecosystem model skill assessment. J. Mar. Sys. 76, 64-82.

Klausmeier, C., Litchman, E., Levin, S., 2004. Phytoplankton growth and stoichiometry under multiple nutrient limitation. Limnol. Oceanogr. 49, 1463-1470.

Kortzinger, A., Koeve, W., Kahler, P., Mintrop, L., 2001. C:N ratios in the mixed layer during the productive season in the northeast Atlantic Ocean. Deep-Sea Research I 48, 661-688.

Kremeur, A.S., Lévy, M., Aumont, O., Reverdin, G., 2009. Impact of the subtropical mode water biogeochemical properties on primary production in the North Atlantic: New insights from an idealized model study. J. Geophys. Res.-Oceans 114, C07019, doi:10.1029/2008JC005161.

Kriest, I., Khatiwala, S., Oschlies, A., 2010. Towards an assessment of simple global marine biogeochemical models of different complexity. Prog. Oceanogr. $86,337-360$.

Lancelot, C., Hannon, E., Becquevort, S., Veth, C., De Baar, H., 2000. Modeling phytoplankton blooms and carbon export production in the Southern Ocean: dominant controls by light and iron in the Atlantic sector in Austral spring 1992. Deep-Sea Research I 47, 1621-1662. 
Le Quéré, C., Harrison, S., Prentice, I., Buitenhuis, E., Aumont, O., Bopp, L., Claustre, H., Da Cunha, L., Geider, R., Giraud, X., Klaas, C., Kohfeld, K., Legendre, L., Manizza, M., Platt, T., Rivkin, R., Sathyendranath, S., Uitz, J., Watson, A., Wolf-Gladrow, D., 2005. Ecosystem dynamics based on plankton functional types for global ocean biogeochemistry models. GLOBAL CHANGE BIOLOGY 11, 2016-2040.

Lefèvre, N., Taylor, A., Gilbert, F., Geider, R., 2003. Modeling carbon to nitrogen and carbon to chlorophyll $a$ ratios in the ocean at low latitudes: Evaluation of the role of physiological plasticity. Limnol. Oceanogr. 48, 1796-1807.

Lévy, M., Gavart, M., Memery, L., Caniaux, G., Paci, A., 2005. A four-dimensional mesoscale map of the spring bloom in the northeast Atlantic (POMME experiment): Results of a prognostic model. J. Geophys. Res.-Oceans 110, C07S21, doi:10.1029/2004JC002588.

Lévy, M., Iovino, D., Resplandy, L., Klein, P., Madec, G., Treguier, A.M., Masson, S., Takahashi, K., 2012. Large-scale impacts of submesoscale dynamics on phytoplankton : local and remote effects. Ocean Modelling 43-44, 77-93. doi:10.1016/j.ocemod.2011.12.003.

Lévy, M., Memery, L., Madec, G., 1998. The onset of a bloom after deep winter convection in the northwestern Mediterranean sea: mesoscale process study with a primitive equation models. J. Mar. Sys. 16, 7-21. 28th International Liege Colloquium on Ocean Hydrodynamics, Liège, Belgium, May 06-10, 1996.

Lipschultz, F., 2001. A time-series assessment of the nitrogen cycle at BATS. Deep-Sea Research I 48, 1897-1924.

Mairet, F., Bernard, O., Masci, P., Lacour, T., Sciandra, A., 2011. Modelling 
neutral lipid production by the microalga Isochrysis aff. galbana under nitrogen limitation. Bioresource Technol. 102, 142-149.

Matear, R., 1995. Parameter optimization and analysis of ecosystem models using simulated annealing: A case study at Station P. J. Mar. Res. 53, 571-607.

McGillicuddy, D., Anderson, L., Doney, S., Maltrud, M., 2003. Eddy-driven sources and sinks of nutrients in the upper ocean: Results from a 0.1 degrees resolution model of the North Atlantic. Global Biogeochemical Cycles 17, doi:10.1029/2002GB001987.

Michaels, A., Knap, A., 1996. Overview of the US JGOFS Bermuda Atlantic Time-series Study and the Hydrostation S program. Deep-Sea Research I 43, $157-198$.

Mitra, A., Flynn, K.J., Fasham, M.J.R., 2007. Accounting for grazing dynamics in nitrogen-phytoplankton-zooplankton models. Limnol. Oceanogr. 52, 649-661.

Mongin, M., Nelson, D., Pondaven, P., Brzezinski, M., Treguer, P., 2003. Simulation of upper-ocean biogeochemistry with a flexible-composition phytoplankton model: C, N and Si cycling in the western Sargasso Sea. Deep-Sea Research I 50, 1445-1480.

Monod, J., 1949. The growth of bacterial cultures. Annu. Rev. Microbiol. 3, $371-394$.

Monod, J., 1950. La technique de culture continue théorie et applications. Ann. I. Pasteur Paris 79, 390-410.

Moore, J., Doney, S., Kleypas, J., Glover, D., Fung, I., 2002. An intermediate complexity marine ecosystem model for the global domain. Deep-Sea Research I 49, 403-462. 
Oschlies, A., 2002. Can eddies make ocean deserts bloom? Global Biogeochemical Cycles 16, doi:10.1029/2001GB001830.

Oschlies, A., Schartau, M., 2005. Basin-scale performance of a locally optimized marine ecosystem model. J. Mar. Res. 63, 335-358.

Redfield, A.C., Ketchum, B.H., Richards, F.A., 1963. The influence of organisms on the composition of sea water, in: Hill, M.N. (Ed.), The sea. Wiley, New York, pp. $26-77$.

Riebesell, U., Schulz, K.G., Bellerby, R.G.J., Botros, M., Fritsche, P., Meyerhoefer, M., Neill, C., Nondal, G., Oschlies, A., Wohlers, J., Zoellner, E., 2007. Enhanced biological carbon consumption in a high CO2 ocean. Nature 450, 545-548.

Ross, O.N., Geider, R.J., 2009. New cell-based model of photosynthesis and photoacclimation: accumulation and mobilisation of energy reserves in phytoplankton. Mar. Ecol. Prog. Ser. 383, 53-71.

Salihoglu, B., Garcon, V., Oschlies, A., Lomas, M.W., 2008. Influence of nutrient utilization and remineralization stoichiometry on phytoplankton species and carbon export: A modeling study at BATS. Deep-Sea Research I 55, 73-107.

Sambrotto, R., Savidge, G., Robinson, C., Boyd, P., Takahashi, T., Karl, D., Langdon, C., Chipman, D., Marra, J., Codispoti, L., 1993. Elevated consumption of carbon relative to nitrogen in the surface oceans. Nature 363, 248-250.

Schartau, M., Oschlies, A., 2003. Simultaneous data-based optimization of a 1Decosystem model at three locations in the North Atlantic: Part I - Method and parameter estimates. J. Mar. Res. 61, 765-793. 
Schartau, M., Oschlies, A., Willebrand, J., 2001. Parameter estimates of a zerodimensional ecosystem model applying the adjoint method. Deep-Sea Research I 48, 1769-1800.

Sciandra, A., 1991. Coupling and uncoupling between nitrate uptake and growth rate in Prorocentrum minimum (Dinophyceae) under different frequencies of pulsed nitrate supply. Mar. Ecol. Prog. Ser. 72, 261-269.

Smith, S.L., Yamanaka, Y., 2007. Quantitative comparison of photoacclimation models for marine phytoplankton. Ecological Modelling 201, 547-552.

Spitz, Y., Moisan, J., Abbott, M., 2001. Configuring an ecosystem model using data from the Bermuda Atlantic Time Series (BATS). Deep-Sea Research I 48, $1733-1768$.

Spitz, Y., Moisan, J., Abbott, M., Richman, J., 1998. Data assimilation and a pelagic ecosystem model: parameterization using time series observations. J. Mar. Sys. 16, 51-68. 28th International Liege Colloquium on Ocean Hydrodynamics, Liège, Belgium, May 06-10, 1996.

Steinberg, D., Carlson, C., Bates, N., Johnson, R., Michaels, A., Knap, A., 2001. Overview of the US JGOFS Bermuda Atlantic Time-series Study (BATS): a decade-scale look at ocean biology and biogeochemistry. Deep-Sea Research I 48, 1405-1447.

Stow, C.A., Jolliff, J., McGillicuddy, Jr., D.J., Doney, S.C., Allen, J.I., Friedrichs, M.A.M., Rose, K.A., Wallhead, P., 2009. Skill assessment for coupled biologi$\mathrm{cal} /$ physical models of marine systems. J. Mar. Sys. 76, 4-15.

Tagliabue, A., Arrigo, K., 2005. Iron in the Ross Sea: 1. Impact on CO2 fluxes via 
variation in phytoplankton functional group and non-Redfield stoichiometry. J. Geophys. Res.-Oceans 110, doi:10.1029/2004JC002531.

Tagliabue, A., Bopp, L., Gehlen, M., 2011. The response of marine carbon and nutrient cycles to ocean acidification: Large uncertainties related to phytoplankton physiological assumptions. Global Biogeochemical Cycles 25, doi:10.1029/2010GB003929.

Taylor, K., 2001. Summarizing multiple aspects of model performance in a single diagram. J.Geophys. Res. 106, 7183-7192.

Vatcheva, I., DeJong, H., Bernard, O., Mars, N.J.L., 2006. Experiment selection for the discrimination of semi-quantitative models of dynamical systems. Artif. Intel. 170, 472-506.

Vichi, M., Masina, S., 2009. Skill assessment of the pelagos global ocean biogeochemistry model over the period 19802000. Biogeosciences 6, 2333-2353.

Vichi, M., Masina, S., Navarra, A., 2007. A generalized model of pelagic biogeochemistry for the global ocean ecosystem. part ii: numerical simulations. Journal of Marine Systems 64(1-4), 110-134.

Vogt, M., Vallina, S.M., Buitenhuis, E., Bopp, L., Le Qur, C., 2010. Simulating dimethylsulphide seasonality with the dynamic green ocean model planktom5. Journal of Geophysical Research - Oceans 115(C6), C06021.

Ward, B.A., Friedrichs, M.A.M., Anderson, T.R., Oschlies, A., 2010. Parameter optimisation techniques and the problem of underdetermination in marine biogeochemical models. J. Mar. Sys. 81, 34-43. Symposium on Advances in Marine Ecosystem Modelling Research, Plymouth, England, Jun 23-26, 2008. 
869

Webb, W., Newton, M., Starr, D., 1974. Carbon dioxide exchange of Alnus rubra: a mathematical model. Oecologia 17, 281-291.

Williams, R., Follows, M., 1998. The Ekman transfer of nutrients and maintenance of new production over the North Atlantic. Deep-Sea Research I 45, 461-489.

Wroblewski, J., 1977. A model of phytoplankton plume formation during variable Oregon upwelling. J. Mar. Res. 35, 357-394.

Zonneveld, C., 1998. Light-limited microalgal growth: a comparison of modelling approaches. Ecological Modelling 113, 41-54. 1st European Ecological Modelling Conference, Pula, Croatia, Sep 16-19, 1997. 